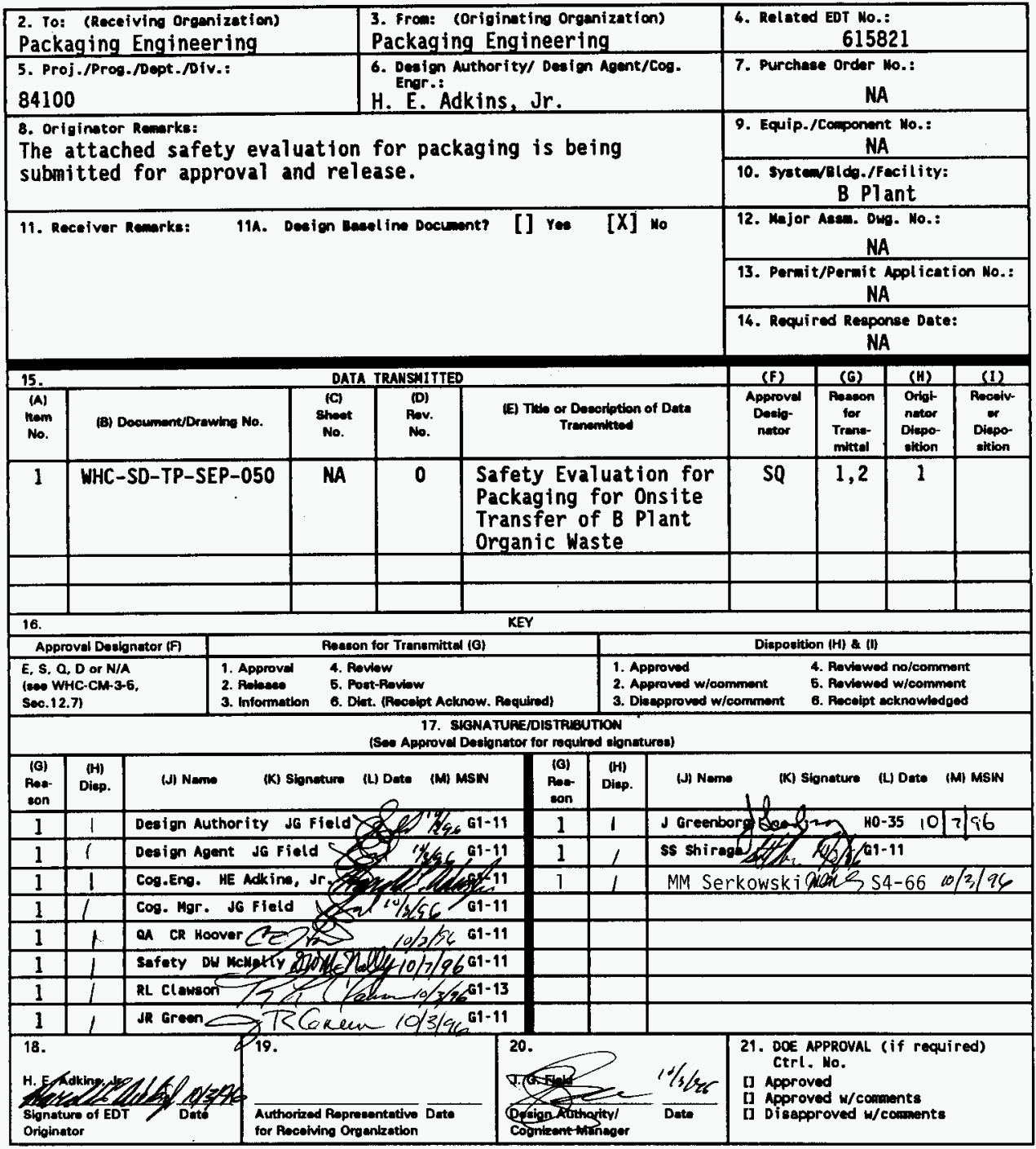

BD-7400-172-2 (05/96) GEF097 


\title{
Safety Evaluation for Packaging for Onsite Transfer of B Plant Organic Waste
}

\author{
H. E. Adkins, Jr.
}

West inghouse Hanford Company, Richland, WA 99352

U.S. Department of Energy Contract DE-ACO6-87RL10930

\begin{tabular}{|c|c|c|}
\hline $\begin{array}{l}\text { EDT/ECN: } \\
\text { Org Code: } \\
\text { B\&R Code: }\end{array}$ & $\begin{array}{l}618183 \\
84100 \\
\text { EW3135090 }\end{array}$ & $\begin{array}{l}\text { UC: } 513 \\
\text { Charge Code: } \\
\text { Total Pages: }\end{array}$ \\
\hline
\end{tabular}

Key Words: tank, radioactive organic liquid waste, organic loading pad, storage pad

Abstract: This safety evaluation for packaging authorizes the use of a 17,500-L (4,623-gal) tank manufactured by Brenner Tank, Incorporated, to transport up to $16,221 \mathrm{~L}(4,285 \mathrm{gal})$ of radioactive organic liquid waste. The waste will be transported from the organic loading pad to a storage pad. Both pads are within the B Plant complex, but approximately mi apart.

TRADEMARK DISCLAINER. Reference herein to any specific commercial product, process, or service by trade name, trademark, menufacturer, or otherwise, does not necesearily conetitute or imply its endorsement, recomenendation, or favoring by the United States Governent or any asency thereof or its contractors or subcentractors.

Printed in the United states of Amorica. To obtain copies of this docunent, contect: wuc/BCs Dacument Control Services, P.0. Box 1970, Msilstop M6-08, Richlend un 99352, Phone (509) 372-2620; Fax (509) $376-4989$.
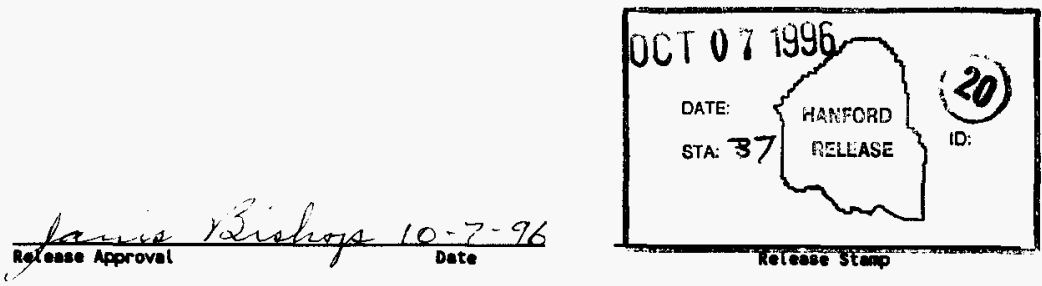

\section{Approved for Public Release}


WHC-SD-TP-SEP-050, Rev. 0

This page intentionally left blank. 
WHC-SD-TP-SEP-050 Rev. 0

CONTENTS

PART A: DESCRIPTION AND OPERATIONS

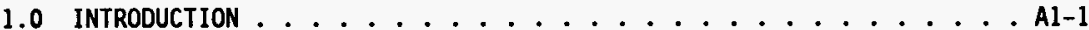

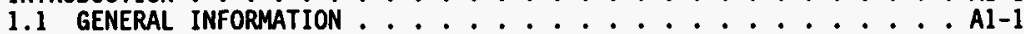

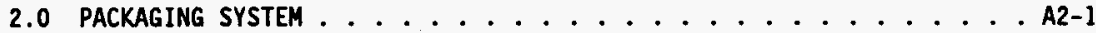

2.1 CONFIGURATION AND DIMENSIONS $\ldots \ldots \ldots \ldots \ldots$. . . . . . . .

2.2 MATERIALS OF CONSTRUCTION .......................

2.3 DESIGN AND FABRICATION METHODS .........................

2.4 WEIGHTS AND CENTER OF GRAVITY . . . . . . . . . . A2-2

2.5 CONTAINMENT BOUNDARY ..........................

2.6 VOLUME (CAVITY SIZE) . . . . . . . . . . . . A2-3

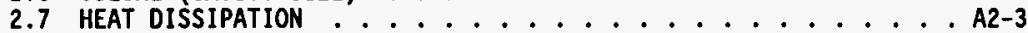

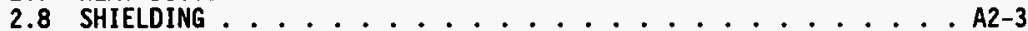

2.9 LIFTING DEVICES . . . . . . . . . . . . . . . . A2-3

2.10 TIEDOWN DEVICES ..........................

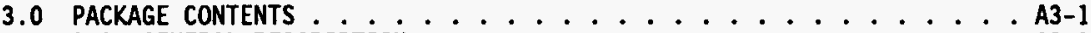

3.1 GENERAL DESCRIPTION ...................... . . .

3.2 CONTENTS RESTRICTIONS ....................... . . .

4.0 TRANSPORT SYSTEM . . . . . . . . . . . . . . . . A4-1

4.1 TRANSPORT VEHICLE . . . . . . . . . . . . . . . . A4-1

4.2 TIEDOWN SYSTEM . . . . . . . . . . . . . . A4-1

4.3 SPECIAL TRANSFER REQUIREMENTS ..................... A4

5.0 ACCEPTANCE OF PACKAGING FOR USE ................ A5-1

6.0 OPERATING REQUIREMENTS ................... . A6-1

6.1 GENERAL REQUIREMENTS ...................... A6-1

6.2 LOADING AND LIFTING THE PACKAGE $\ldots \ldots \ldots$

7.0 QUALITY ASSURANCE ................... A7-1

7.1 GENERAL REQUIREMENTS .................. . A7-1

7.2 SEP CONTROL SYSTEM ......................... A7-1

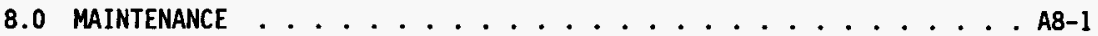

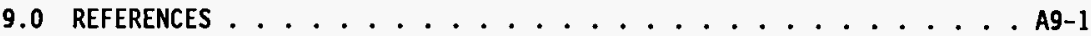

10.0 APPENDIX: CERTIFICATION ...................... AlO-1 
WHC-SD-TP-SEP-050 Rev. 0

CONTENTS (cont.)

PART B: PACKaGe EVALUATION

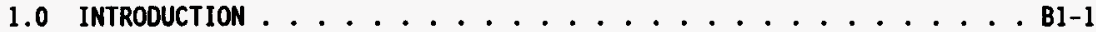

1.1 SAFETY EVALUATION METHODOLOGY .............. B1-1

1.2 EVALUATION SUMMARY AND CONCLUSION ............. B1-1

1.3 REFERENCES ...........................

2.0 CONTENTS EVALUATION . . . . . . . . . . . . . . B2-1

2.1 CHARACTERIZATION ...................... B2-1

2.1.1 Source Term . . . . . . . . . . . B2-1

2.1 .2 Source Term Classification ........... B2-2

2.2 RESTRICTIONS ...................... B2-5

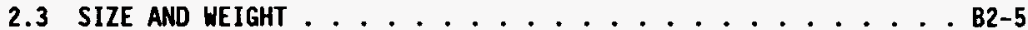

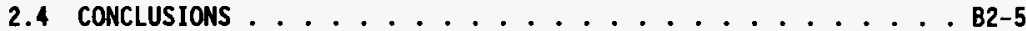

2.5 REFERENCES ........................... B2-5

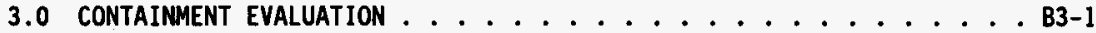

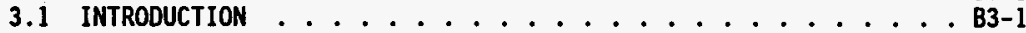

3.2 CONTAINMENT SOURCE SPECIFICATION ............ B3-1

3.3 NORMAL TRANSFER CONDITIONS .............. B3-1

3.3.1 Conditions To Be Evaluated . . . . . . . . . . B3-1

3.3.2 Release Acceptance Criteria ........... B3-1

3.4 CONTAINMENT EVALUATION AND CONCLUSIONS .......... B3-1

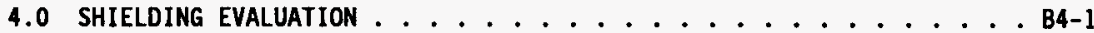

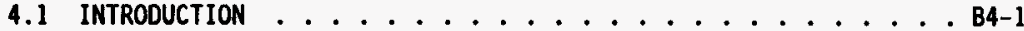

4.2 DIRECT RADIATION SOURCE SPECIFICATION ........... B4-1

4.2.1 Photon Source .................. B4-1

4.2.2 Beta Particle Source . . . . . . . . . . . . . B4-1

4.2.3 Neutron Source . . . . . . . . . . B4-1

4.3 SUMMARY OF SHIELDING PROPERTIES OF MATERIALS ....... B4-1

4.4 NORMAL TRANSFER CONDITIONS ............. B4-2

4.4.1 Conditions To Be Evaluated ............. B4-2

4.4.2 Acceptance Criteria ............... B4-2

4.4.3 Shielding Model ............... B4-3

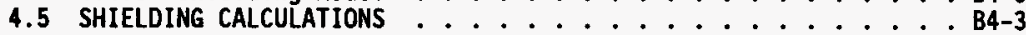

4.6 REFERENCES .......................... B4-4

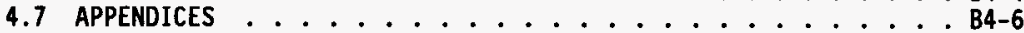

4.7.1 Checklist for Independent Technical Review ....... B4-6

4.7.2 Computer Input Files ............. B4-8

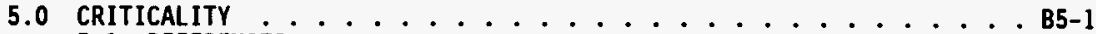

5.1 REFERENCES .......................... B5-1

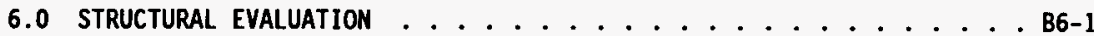

6.1 INTRODUCTION $\ldots \ldots \ldots$ B6-1

6.2 STRUCTURAL EVALUATION OF PACKAGE $\ldots \ldots \ldots \ldots$

6.2.1 Structural Design and Features . . . . . . . B6-1

6.2.2 Mechanical Properties of Materials . . . . . . B6-1 
CONTENTS (cont.)

6.2.3 Chemical and Galvanic Reactions ........... B6-1

6.2.4 S1ze of Package and Cavity ............. B6-1

6.2.5 Weights and Center of Gravity ........... B6-1

6.2.6 Tamper-Indicating Feature ........... B6-1

6.2.7 Positive Closure . . . . . . . . . . . . B6-1

6.2.8 Lifting and Tiedown Devices ........... B6-2

6.2.9 Brittle Fracture ............... B6-2

6.3 MORMAL TRANSFER CONDITIONS ............ B6-2

6.3.1 Conditions To Be Evaluated ........... B6-2

6.4 STRUCTURAL EVALUATION AND CONCLUSIONS ........... B6-2

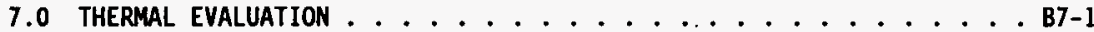

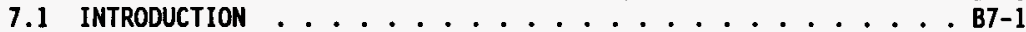

7.2 THERMAL SOURCE SPECIFICATION ............. B7-1

7.3 SUMMARY OF THERMAL PROPERTIES OF MATERIALS $\ldots \ldots \ldots \ldots$

7.4 THERMAL EVALUATION AND CONCLUSIONS ............ B7-1

7.5 REFERENCES ......................... B7-1

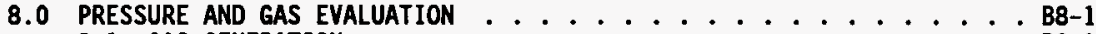

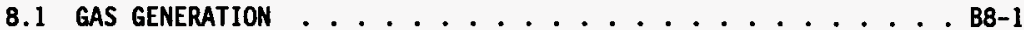

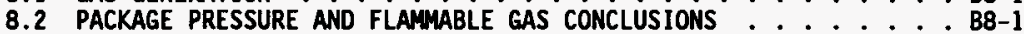

8.3 APPENDIX: HYDROGEN GENERATION EVALUATIONS ......... B8-2

9.0 PACKAGE TIEDOWN SYSTEM EVALUATION ............... B9-1

9.1 SYSTEM DESIGN . . . . . . . . . . . . . . . . B9-1

9.2 ATTACHMENTS AND RATINGS . . . . . . . . . . . Bg-1

\section{LIST OF TABLES}

A3-1 B Plant Organic Waste Source Term ............. . A3-1

A4-1 Removable External Radioactive Contamination--Wipe Limits . . . . A4-2

B2-1 B P1 ant Organic Waste Source Term .............. B2-3

B2-2 Low Specific Activity Determination ................. B2-4

B4-1 B Plant Organic Waste Source Term ............... B4-2

B4-2 Tank Dimensions Used in Calculations : . . . B . . B

B4-3 Effective Dose Equivalent . . . . . . . . . . . . . . . B5-4

B5-1 Masses of Fissile Isotopes ................. B5-1 


\section{LIST OF TERHS}

$\begin{array}{ll}\text { ALARA } & \text { as low as reasonably achievable } \\ \mu \mathrm{Ci} / \mathrm{mL} & \text { microcuries per milititer } \\ \mathrm{Ci} & \text { curie } \\ \mathrm{Ci} / \mathrm{g} & \text { curies per gram } \\ \mathrm{Cm} & \text { centimeter } \\ \mathrm{cm}^{3} & \text { cubic centimeter } \\ \mathrm{Cm}^{3} / \mathrm{h} & \text { cubic cent imeters per hour } \\ \mathrm{DOT} & \text { U.S. Department of Transportation } \\ \mathrm{dpm} / \mathrm{cm}^{2} & \text { disintegrations per minute per square centimeter } \\ \mathrm{ft} & \text { foot } \\ \mathrm{g} & \text { gram } \\ \mathrm{gal} & \text { gallon } \\ \mathrm{g} / \mathrm{cm} & \text { grams per cubic centimeter } \\ \text { in. } & \text { inch } \\ \mathrm{ISO} & \text { International standards organization } \\ \mathrm{kg} & \text { kilogram } \\ \mathrm{L} & \text { liter } \\ \mathrm{Ib} & \text { pound } \\ \mathrm{LSA} & \text { low specific act ivity } \\ \mathrm{km} / \mathrm{h} & \text { kilometers per hour } \\ \mathrm{kPa} & \text { kilopascal } \\ \mathrm{m} & \text { meter } \\ \mathrm{MeV} & \text { megaelectronvolts } \\ \mathrm{MPa} & \text { megapascal } \\ \mathrm{mph} & \text { miles per hour } \\ \mathrm{mrem} / \mathrm{h} & \text { millirem per hour } \\ \mathrm{mSv} / \mathrm{h} & \text { millisevert per hour } \\ \mathrm{MTIU} & \text { metric tonne of initial uranium } \\ \mathrm{Oz} & \text { ounce } \\ \mathrm{psi} & \text { pounds per square inch } \\ \mathrm{psig} & \text { pounds per square inch gage } \\ \mathrm{rem} / \mathrm{h} & \text { rem per hour } \\ \mathrm{SEP} & \text { safety evaluation for packaging } \\ \mathrm{SI} & \text { standard international system of units } \\ \mathrm{W} & \text { watt } \\ & \end{array}$


WHC-SD-TP-SEP-050 Rev. 0

SAFETY EYALUATION FOR PACKAGING FOR ONSITE

TRANSFER OF B PLANT ORGANIC MASTE

PART A: DESCRIPTION AND OPERATIONS

\subsection{INTRODUCTION}

\subsection{GENERAL INFORMTION}

The purpose of this safety evaluation for packaging (SEP) is to authorize the use of a 17,500-L (4,623-gal) tank manufactured by Brenner Tank, Incorporated, to transport up to $16,221 \mathrm{~L}(4,285 \mathrm{gal})$ of radioactive organic 1 iquid waste. This liquid waste was originally stored in cells 27 and 28 within the B Plant canyon. The tank containing the waste will be transported from the organic loading pad to a storage pad. Both pads are within the B Plant complex, but approximately mi apart. The tank was previously certified for offsite shipment of low specific activity material as is presented in Part $A$, Section 2.1, of this SEP; however, the tank has since been modified to aliow for passive venting during storage. The tank will be sealed during any transport operations. 
WHC-SD-TP-SEP-050 Rev. 0

This page intentionally left blank. 
WHC-SD-TP-SEP-050 Rev. 0

\subsection{PACKaging SySteM}

\subsection{CONFIGURATION AND DIMENSIONS}

The tank assembly was manufactured by Brenner Tank, Incorporated. It consists of a cylindrical tank shell with hemispherical heads and an International Standards Organization (ISO) twist-lock-compatible frame assembly. The twist-lock corner fittings provide a means for tiedown and mate with corresponding fittings on an ISO-compatible trafler. The tank modifications include the addition of two filtered vents that will bolt to existing flanges. In its original configuration, the tank met the requirements of the Specification for ISO Tank Container Greater than 1000 Gallons Internal Volume for Shipment of Nitrating Liquids Greater than 50\% Nitric Acid (WHC 1994) and was certified by the American Bureau of Shipping to meet the following codes, specifications, and performance criteria (the certification is presented in Part A, Section 10.0):

- American Bureau of Shipping rules for the certification of cargo containers

- International Convention for Safe Containers

- International Maritime Dangerous Goods Code for International Maritime Organization Type 1 (Type 1 portable tanks)

- International Regulation Concerning the Carriage of Dangerous Goods Code/European Agreement Concerning International Transportation of Dangerous Goods by Rail

- American Association of Railroads 600

- Customs/Transportation International Routier

- U.S. Department of Transportation (DOT) Specification 51 (49 CFR 178.245)

- Transport Canada 51

- Design temperatures $-28.8^{\circ} \mathrm{C}\left(-20^{\circ} \mathrm{F}\right)$ to $121^{\circ} \mathrm{C}\left(+250^{\circ} \mathrm{F}\right)$

- Design pressure $0.69 \mathrm{MPa}$ (100 psig)

- Test pressure $1.06 \mathrm{MPa}$ (154 psig).

Dimensions are as follows:

- Outside she11 length (includes heads):

- Outside shell diameter:

$591.66 \mathrm{~cm}(23215 / 16 \mathrm{in.})$

- Shell thickness (minimum): $200.57 \mathrm{~cm}$ (78.965 in.)

- Head thickness (minimum):

- Capacity (maximum):

$0.75 \mathrm{~cm}(0.295 \mathrm{in}$.

$1.11 \mathrm{~cm}(0.438 \mathrm{in.})$ $17,500 \mathrm{~L}(4,623 \mathrm{gal})$. 
WHC-SD-TP-SEP-050 Rev. 0

The modifications consist of the following:

- Adding a 30.48-cm- (12-in.-) square Flanders Nuclear Grade Super Flow high-efficiency particulate air filter (Model N2N2, Size CC-D) to the existing air inlet valve

- Adding 12.7-cm- (5-in.-) long, 6.35-cm- (2.5-in.-) inside diameter extension from the air inlet valve into the interior of the tank

- Replacing the pressure vent assembly with a valve and filter (same valve and filter used on the air inlet valve, but with no extension into the tank)

- Adding a hydrogen vent to the top of the large and small spilldam assemblies.

\subsection{MATERIALS OF CONSTRUCTION}

The tank shell is constructed of 304 or $304 \mathrm{~L}$ stainless steel. The frame assembly is constructed from various grades of carbon or high-strength lowalloy steel.

\subsection{DESIGN AND FABRICATION METHODS}

The tank assembly was designed and fabricated per ASME (1992).

\subsection{MEIGHTS AND CENTER OF GRAVITY}

The center of gravity of the loaded tank is assumed to be at the geometric center of the shell. The maximum gross weight per the certificate of approval (see Part A, Section 10.0) is $30,480 \mathrm{~kg}(67,200 \mathrm{lb})$. Actual weights will be less and are approximately as follows:

- Tank assembly: 4,604 $\mathrm{kg}(10,150 \mathrm{lb})$

- Payload (conservatively assumes $17,500 \mathrm{~L}[4,623 \mathrm{gal}]$ and a specific gravity of l): $25,876 \mathrm{~kg}(38,581 \mathrm{lb})$.

\subsection{CONTAINMENT BOUNDARY}

The containment boundary consists of the following:

- Shell walls and heads

- 69.85-cm (27.5-in.) blind manhole flange

- 3.81-cm (1.5-in.) blind top discharge flange

- Blind process control flange 
- Air inlet valve

- Valve that will bolt to the flange for the pressure vent/telltale gauge/burst disc assembly (this valve will be identical to the valve used on the air inlet valve).

\subsection{VOLUME (CAVITY SIZE)}

The tank has a capacity of $17,500 \mathrm{~L}(4,623 \mathrm{gal})$. Maximum allowable waste volume will be $16,221 \mathrm{~L}(4,285$ gal).

\subsection{HEAT DISSIPATION}

There are no special features required to dissipate heat. Passive heat dissipation is sufficient (see Part B, Section 7.0).

\subsection{SHIELDING}

Shielding is provided by the tank shell and heads. See Part B, Section 4.0 , for dose rates.

\subsection{LIFTING DEVICES} assembly.

There are four twist-lock attachments at the top corners of the frame

\subsection{TIEDOHN DEVICES}

The tank will be attached to the trailer via the four twist-lock fittings on the bottom of the frame assembly. 
WHC-SD-TP-SEP-050 Rev. 0

This page intentionally left blank. 
WHC-SD-TP-SEP-050 Rev. 0

\subsection{PACKAGE CONTENTS}

\subsection{GENERAL DESCRIPTION}

The tank is authorized for up to $16,221 \mathrm{~L}(4,285 \mathrm{gal})$ of radioactive organic liquid waste from the B Plant canyon.

\subsection{CONTENTS RESTRICTIONS}

The isotopic content contained in the liquid is 1 imited to that presented in Table A3-1. There shall be no additional radioactive or hazardous component contained within the Iiquid.

Table A3-1. B Plant Organic Waste Source Term. (2 sheets total)

\begin{tabular}{|c|c|c|c|c|c|c|}
\hline Isotope & $\begin{array}{l}\text { Alphe } \\
\text { yield }\end{array}$ & $\begin{array}{l}\text { Eete } \\
\text { yield }\end{array}$ & $\begin{array}{c}\text { ci/ntiv } \\
12 x \text { fuel }\end{array}$ & 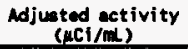 & 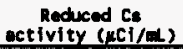 & $\begin{array}{c}\text { Total activity } \\
\text { (Ci) }\end{array}$ \\
\hline${ }^{85} \mathrm{Kr}$ & & 1.000 & $5.03 E+02$ & $6.49 \mathrm{E}-01$ & $6.49 \mathrm{E}-01$ & $1.13 E+01$ \\
\hline${ }^{\circ} \mathrm{sr}$ & & 1.000 & $5.78+03$ & $7.45 \mathrm{E}+00$ & $7.45 E+\infty 0$ & $1.30 \mathrm{E}+02$ \\
\hline $90_{Y}$ & & 1.000 & $5.78 \mathrm{E}+03$ & $7.45 E+\infty 0$ & $7.45 E+00$ & $1.30 \mathrm{E}+02$ \\
\hline $932 r$ & & 1.000 & 1.71 E-01 & 2.21 E-06 & $2.21 E-04$ & 3.84 E-03 \\
\hline${ }^{*} T_{C}$ & & 1.000 & $1.26 E+\infty$ & $1.62 E-03$ & $1.62 E-03$ & $2.83 E-02$ \\
\hline 106 & & 1.000 & $5.23 E+01$ & $6.75 E-02$ & 6.75 E-02 & $1.18 E+00$ \\
\hline & & 1.000 & $5.23 E+01$ & 6.75 E-02 & $6.75 E-02$ & $1.18 E+00$ \\
\hline & & & $2.35 E+\infty 0$ & $3.04 \varepsilon-03$ & $3.04 E-03$ & 5.29 E-02 \\
\hline & & 0.909 & $1.25 E+02$ & 1.61 E-01 & $1.61 E-04$ & $2.80 \mathrm{E}+00$ \\
\hline ?e & & & $3.04 E+01$ & $3.92 \varepsilon-02$ & $3.92 E-02$ & 6.83 E-01 \\
\hline & & 1.000 & $1.27 \mathrm{E}+02$ & $1.64 E-01$ & $1.21 E-02$ & $2.10 \mathrm{E}-01$ \\
\hline & & 1.000 & $7.29 E+03$ & $3.89 E+\infty 0$ & $2.86 E-01$ & $4.98 \mathrm{E}+00$ \\
\hline & & & $6.90 E+03$ & $3.68 E+\infty 0$ & $2.71 E-01$ & $4.71 E+00$ \\
\hline & & 1.015 & $2.79 E+01$ & 3.60 E-02 & $3.60 E-02$ & 6.26 E-01 \\
\hline & & 1.000 & $2.79 E+01$ & 3.60 E-02 & $3.60 E-02$ & 6.26 E-01 \\
\hline & & & 3.35 E-01 & $4.32 E-04$ & $4.32 E-04$ & 7.52 E-03 \\
\hline & & 1.000 & $1 . \%$ E+03 & $2.52 \mathrm{E}+00$ & $2.52 E+00$ & $4.39 E+01$ \\
\hline & & 1.000 & $8.95 E+01$ & $1.15 E-01$ & $1.15 \mathrm{E}-01$ & $2.01 E+00$ \\
\hline & & 0.710 & $6.51 \in-01$ & 8.41 E-04 & $8.41 E-04$ & 1.46 E-02 \\
\hline & & 1.000 & $8.80 \mathrm{E}+01$ & $1.16 E-01$ & 1.16 E-01 & $1.98 E+\infty 0$ \\
\hline & & 1.010 & $3.48 \mathrm{E}+01$ & $4.49 E-02$ & $4.49 \mathrm{E}-02$ & 7.82 E-01 \\
\hline & & 1.001 & 3.32 E-01 & 1.52 E-06 & 1.52 E-06 & $2.65 E-05$ \\
\hline & & 1.000 & 3.32 E-01 & $1.52 \mathrm{E}-06$ & 1.52 E-06 & 2.65 E-05 \\
\hline $234 \mathrm{v}$ & 1.000 & & 4.23 E-01 & 1.9 E-06 & 1.94 E-06 & $3.38 E-05$ \\
\hline $7 u$ & & 1.010 & 1.09 E-01 & 5.00 E-07 & 5.00 E-07 & 8.71 E-06 \\
\hline
\end{tabular}


WHC-SD-TP-SEP-050 Rev. 0

Table A3-1. B Plant Organic Waste Source Term. (2 sheets total)

\begin{tabular}{|c|c|c|c|c|c|c|}
\hline${ }^{238} \mathrm{u}$ & 1.002 & & 3.32 E-01 & 1.52 E-06 & 1.52 E-06 & $2.65 E-05$ \\
\hline${ }^{238} \mathrm{Pu}$ & 1.000 & & $4.77 E+01$ & $2.19 \mathrm{E}-04$ & 2.19 E-04 & $3.81 E-03$ \\
\hline $23 \% \mathrm{Pu}$ & 0.999 & & $1.10 E+02$ & 5.05 E-04 & 5.05 E-04 & 8.79 E-03 \\
\hline $240 \mathrm{Pu}$ & 1.000 & & $5.82 \mathrm{E}+01$ & $2.67 E-04$ & 2.67 E-06 & $4.65 E-03$ \\
\hline 261 & 0.000 & 1.000 & $4.45 E+03$ & 2.04 E-02 & $2.04 E-02$ & $3.55 E-01$ \\
\hline $261_{A n}$ & 1.000 & & $9.29 \mathrm{E}+01$ & $4.26 E-04$ & $4.26 E-04$ & $7.42 \varepsilon-03$ \\
\hline 2420 & 0.005 & & 1.08 E-01 & 4.96 E-07 & 4.96 E.07 & $8.64 E \cdot 06$ \\
\hline $242 \mathrm{Am}$ & & 0.827 & $1.08 E-01$ & 4.93 E-07 & 4.93 E-07 & $8.59 E-06$ \\
\hline \multicolumn{6}{|c|}{ Total activity } & $3.37 \mathrm{E}+02$ \\
\hline \multicolumn{2}{|c|}{ Iotal bete } & \multicolumn{2}{|c|}{$2.64 \mathrm{E}+04 \mathrm{Ci}$} & $2.28 \mathrm{E}+01$ & $1.90 \mathrm{E}+01$ & $3.32 \quad \mathrm{E}+02$ \\
\hline \multicolumn{2}{|c|}{ Total alphe } & \multicolumn{2}{|c|}{$3.10 \mathrm{E}+02 \mathrm{CI}$} & 1.42 E- 03 & $1.42 E-03$ & $2.47 \mathrm{E}-02$ \\
\hline
\end{tabular}

MTIU = Matric tonne of initial uraniun. 
WHC-SD-TP-SEP-050 Rev. 0

\subsection{TRANSPORT SYSTEM}

\subsection{TRANSPORT VEHICLE}

The tank shall be transported on a trailer of appropriate capacity for the maximum gross package weight. The trailer shall have twist-lock devices that interlock with the twist-lock fasteners on the package.

\subsection{TIEDOWN SYSTEN}

Tiedown shall be via the twist-lock fasteners.

\subsection{SPECIAL TRANSFER REQUIREMENTS}

The following special transfer requirements shall be met.

- Only up to $16,221 \mathrm{~L}(4,285 \mathrm{gal})$ of radioactive organic liquid waste will be allowed. This is to provide proper inner ventilation space during storage.

- The section of the road on which the shipment will be transported shall be closed to the public and nonessential workers.

- A11 workers involved in transport, including the driver, shall be qualified Hanford Site radiological workers.

- Dose rates shall be below $2.0 \mathrm{mSv} / \mathrm{h}(200 \mathrm{mrem} / \mathrm{h})$ at the surface of the vehicle, $0.10 \mathrm{mSv} / \mathrm{h}(10 \mathrm{mrem} / \mathrm{h})$ at $2.0 \mathrm{~m}(6.56 \mathrm{ft})$ from the vehicle edge, and $0.05 \mathrm{mSv} / \mathrm{h}(5 \mathrm{mrem} / \mathrm{h})$ at the driver location or any normally occupied space provided the worker is a Hanford Site radiological worker.

- The 2.0-m (6.56-ft) dose rate may exceed the 1 imit of $0.10 \mathrm{mSv} / \mathrm{h}$ (10 mrem/h) and may be up to $0.35 \mathrm{mSv} / \mathrm{h}(35 \mathrm{mrem} / \mathrm{h})$ provided all special requirements above are met (roads closed to public and nonessential workers, qualified radiological workers only).

- When stationary, the controls specified in HSRCM-1, Hanford Site Radiological Control Manual, apply, including any posting for personnel exclusion areas.

- The transport vehicle shall conform to DOT annual inspection requirements found in 49 CFR 396.3, "Inspection, Repair, and Maintenance," and 49 CFR 396.17, "Periodic Inspection."

- Prior to loading of tank and subsequent transport, the tank assembly (tank and frame including twist-locks) shall be visually inspected to ensure that there is no damage or deterioration.

- Transport vehicle speed will be limited to $48.3 \mathrm{~km} / \mathrm{h}$ (30 mph) unless a lower speed is posted. 
- The tank will not be transferred during periods of inclement weather; 1.e., winds in excess of $48.3 \mathrm{~km} / \mathrm{h}$ (35 $\mathrm{mph})$, heavy rain, blowing dust or fog that results in poor visibility, or slippery roads.

- The requirements of WHC-CM-2-14, Hazardous Material Packaging and Shipping, shall be met.

- During transfer conditions, removable contamination on the exterior surfaces of the tanks shall not exceed the DOT limits shown in Table A4-1 when measured per 49 CFR 173.443(a).

- Tank valves shall be closed during transport and only for a maximum allowable time of 150 hours.

Table A4-1. Removable External Radioactive Contamination--Wipe Limits.

\begin{tabular}{|c|c|}
\hline Conteminant & $\begin{array}{c}\text { Moxima permisajble } \\
\text { linit (con/cni) }\end{array}$ \\
\hline 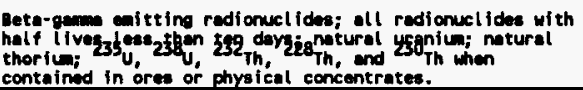 & 22 \\
\hline All other elphe-enitt ing redionucl ides. & 2.2 \\
\hline
\end{tabular}




\section{WHC-SD-TP-SEP-050 Rev. 0}

\subsection{ACCEPTANCE OF PACKAgING FOR USE}

The tanks shall be inspected prior to shipping to ensure that there is no damage or deterioration that would impair the function of the tank. The gaskets and sealing surfaces shall be inspected prior to loading to ensure that they are clean and free from large scratches, dents, or other deformations that would prevent them from sealing. 
WHC-SD-TP-SEP-050 Rev. 0

This page intentionally left blank. 


$$
\text { WHC-SD-TP-SEP-050 Rev. } 0
$$

\subsection{OPERATING REQUIREMENTS}

\subsection{GENERAL REQUIREMENTS}

All packaging and shipping operations shall be as required by WHC-CM-2-14 and this SEP. All operations shall follow the Hanford Site "Master Safety Rules" referenced in WHC-CM-1-10, Safety Manual, and the applicable Occupational Safety and Health Administration standards per 29 CFR 1910.

\subsection{LOADING AND LIFTING THE PACKAGE}

The tank shall be loaded while in place on the trailer. The tank may be lifted at the destination using appropriate lifting devices that attach to the top corner twist-lock fittings. All lifting equipment shall meet the requirements of the Hanford Site Hoisting and Rigging Manual (DOE-RL 1993). 
WHC-SD-TP-SEP-050 Rev. 0

This page intentionally left blank. 
WHC-SD-TP-SEP-050 Rev. 0

\subsection{QUALITY ASSURANCE}

\subsection{GENERAL REQUIREMENTS}

The cognizant facility Quality Assurance personnel are responsible for the following.

1. Verifying that the tank assembly is in unimpaired physical condition and displays no visual defects that could adversely affect the performance of the packaging.

2. Verifying that all special packaging instructions (as applicable) for filling, closing, and preparing the tank for shipment have been followed.

3. Ensuring that appropriate documentation is prepared and retained in accordance with WHC-CM-2-14; WHC-CM-4-2, Quality Assurance; and Quality Assurance Program Plan for the Hazardous Materials Transportation and Packaging Program (WHC 1995).

\subsection{SEP CONTROL SYSTEM}

This SEP will expire immediately following the shipment or one year from the document release date, whichever is first. 
WHC-SD-TP-SEP-050 Rev. 0

This page intentionally left blank.

A7-2 
WHC-SD-TP-SEP-050 Rev. 0

\subsection{MAINTENANCE}

This SEP authorizes only a single transfer of the tank, and as a result, there are no transportation maintenance requirements. The tank must meet the requirements of Part $A$, Section 5.0, prior to shipping. 
WHC-SD-TP-SEP-050 Rev. 0

This page intentionally left blank. 
WHC-SD-TP-SEP-050 Rev. 0

\subsection{REFERENCES}

29 CFR 1910, 1996, "Occupational Safety and Health Standards, "Code of Federal Regulations, as amended.

49 CFR 173, 1996, "Transportation," Code of Federal Regulations, as amended.

49 CFR 396, 1996, "Inspection, Repair, and Maintenance," Code of Federal Regulations, as amended.

ASME, 1992, ASME Boiler and Pressure Vessel Code, Section VIII, Division I, American Society of Mechanical Engineers, New York, New York.

DOE-RL, 1993, Hanford Site Hoisting and Rigging Manual, DOE/RL-92-36, Rev. O, U.S. Department of Energy, Richland Operations Office, Richland, Washington.

HSRCM-1, Hanford Site Radiological Control Manual, Pacific Northwest Laboratory, Richland, Washington.

WHC-CM-1-10, Safety Manual, Hestinghouse Hanford Company, Richland, Washington.

WHC-CM-2-14, Hazardous Materfal Packaging and Shipping, Westinghouse Hanford Company, Richland, Washington.

WHC-CM-4-2, Quality Assurance, Westinghouse Hanford Company, Richland, Washington.

WHC, 1995, Quality Assurance Progran Plan for the Hazardous Materials Transportation and Packaging Progran, WHC-IP-0705, Rev. 1, Westinghouse Hanford Company, Richland, Washington.

WHC-S-0269, 1994, Specification for ISO Tank Container Greater than 1000 Gallons Internal Volume for Shipment of Nitrating Liquids Greater than $50 \%$ Nitric Acid, Westinghouse Hanford Company, Richland, Washington, February 28. 
WHC-SD-TP-SEP-050 Rev. 0

This page intentionally left blank. 


\subsection{APPENDIX: CERTIFICATIOH}

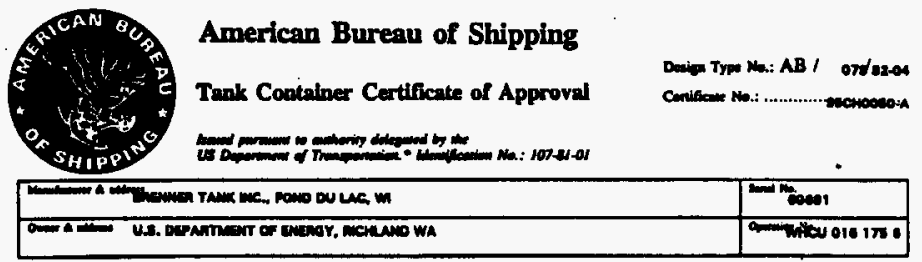

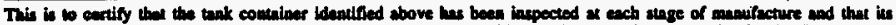
conetruction, including detulle of design, metorivis and workmenship, conforms to the ABS Rules for the Certification of Carpo Comtuiners, to the Internetional Convention of Safe Conkinans and to the following:

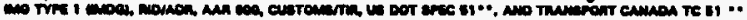

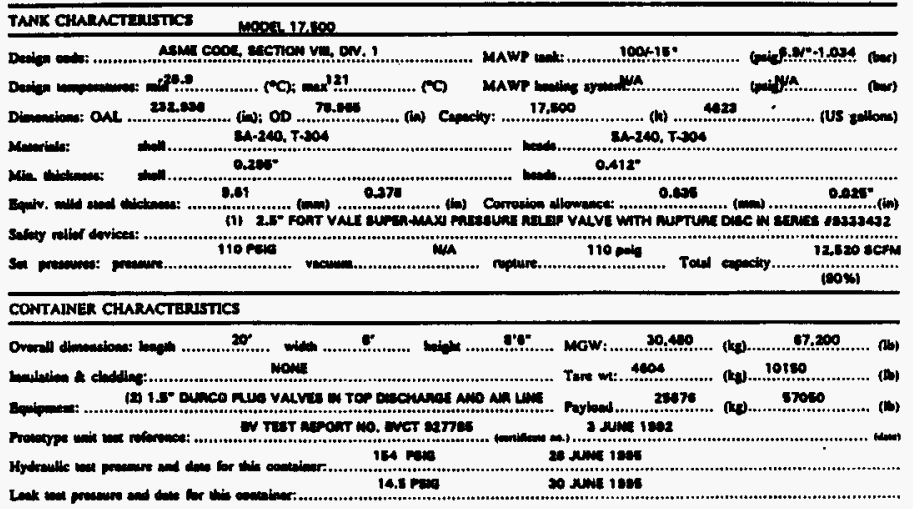

MANUFACTURERS STATEMENT

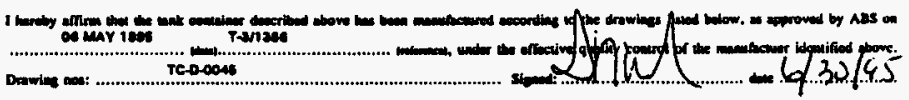

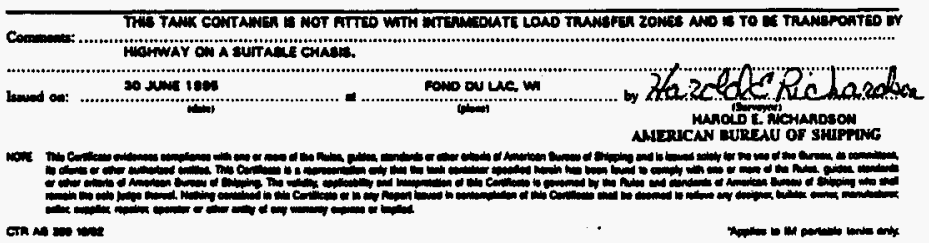


WHC-SD-TP-SEP-050 Rev. 0

This page intentionally left blank.

A10-2 
WHC-SD-TP-SEP-050 Rev. 0

\section{PART B: PACKAGE EVALUATION}

\subsection{INTRODUCTION}

\subsection{SAFETY EVALUATION METHODOLOGY}

The tank was analyzed against the requirements of WHC-CM-2-14, Hazardous Materials Packaging and Shipping, for onsite transportation of Type B material. The onsite normal transfer conditions are analyzed, and the tanks meet the criteria for those conditions. Accident conditions were not analyzed because prior to modification the tank was certified for offsite shipment of this type of payload. The primary purpose of this safety evaluation for packaging (SEP) is to address modifications to the tank, problems associated with hydrogen generation, capability to ship a payload less than $80 \%$ by volume, and to address dose rates which exceed normal specified limits.

\subsection{EVALUATION SUMMARY AND CONCLUSION}

The tank is safe for the onsite transportation of organic waste as demonstrated by this SEP.

The contents evaluated as acceptable is $16,500 \mathrm{~L}(4,600 \mathrm{gal})$ of organic waste from the B Plant canyon. However, only 16,221 L (4,285 gal) will be allowed to provide proper vent space during storage. The contents evaluation is presented in Part B, Section 2.0.

A radiological risk evaluation was not performed because there is no need to address accident conditions based on the payload meeting low specific activity (LSA)-II.

Containment is maintained throughout all normal transfer conditions. The containment evaluation is presented in Part B, Section 3.0 .

The shielding evaluation demonstrates that the tanks can be transferred in a manner consistent with as low as reasonably achievable (ALARA) practices. The tank shielding and payload, coupled with special transfer requirements as outlined in Part A, Section 4.3, meet the onsite dose rate requirements for shipping LSA-II material. The shielding evaluation is presented in Part B, Section 4.0.

Subcriticality is maintained in all conditions due to the small quantity of fissile materials. The criticality analysis is presented in Part $B$, Section $\mathbf{5 . 0}$

The structural evaluation concludes that the loaded tank can be loaded, lifted, and transported safely. The structural evaluation is presented in Part B, Section 6.0. 
The thermal evaluation indicates that heat generation is not a concern due to the very small amount of thermal energy created by the payload. The thermal evaluation is presented in Part B, Section 7.0.

Gas generation analyses show that the equilibrium hydrogen concentration in the tank will be $2 \%$ (with the filters open), and once the filter isolation valves are closed for shipping, it will take 150 hours to reach $2.5 \%$ hydrogen concentration within the gaseous layer. The gas generation analyses are presented in Part B, Section 8.0.

The tiedown analysis shows that the system meets the U.S. Department of Transportation (DOT) requirements for load securement. The tiedown analysis is presented in Part B, Section 9.0.

\subsection{REFERENCES}

WHC-CM-2-14, Hazardous Materials Packaging and Shipping, Westinghouse Hanford Company, Richland, Washington. 
WHC-SD-TP-SEP-050 Rev. 0

\subsection{CONTENTS EVALUATION}

\subsection{CHARACTERIZATION}

A maximum of $16,221 \mathrm{~L}(4,285$ gal) of organic waste will be transferred from the B Plant canyon to the B Plant organic tank storage pad. The waste consists of $70 \%$ normal paraffin hydrocarbon, $10 \%$ tributy 1 phosphate, and $20 \%$ di-2 ethylhexyl phosphoric acid. The liquid has a specific gravity of 0.85 and is contaminated with the radioactive source term shown below.

NOTE: For source term determination, a payload of $17,413 \mathrm{~L}$ (4,600 gal) was assumed, for conservatism.

\subsubsection{Source Term}

The spreadsheet Quattro' Pro was used to extract isotopic information from a brace of laboratory analyses that reported merely the total alpha, beta, and gamma counts. A quick check of the relative influence of the various isotopes to the total gamma-ray spectrum was made using the program ISOSHLD (Engel et al. 1966, Simmons et al. 1967, Rittmann 1995).

\subsubsection{Assumptions. The following assumptions were made.}

- The gamma-ray count is entirely the result of ${ }^{137} \mathrm{Ba}$. The use of this assumption implicitly assumes that the detector used discriminates against gamma-ray energies lower than $0.66 \mathrm{MeV}$ and that the interference from other gamma rays and/or Bremsstrahlung at this energy is negligible.

- The mix of isotopes is that of 10-year aged $12 \%{ }^{240} \mathrm{Pu} \mathrm{N}$ Reactor fuel. This is a conservative assumption.

2.1.1.2 Input Data. Two organic waste samples are analyzed, and the results are averaged. They are then used in the tabulation of Table B2-1. A more thorough description of the input can be found in Source Term for the B-Plant Organic Waste (Goldberg 1996), which develops the activity concentration. The data from that reference are multiplied by the assumed payload volume, $1.7413 \times 10^{7} \mathrm{~cm}^{3}\left(4.6 \times 10^{3} \mathrm{gal}\right)$, to obtain the total source.

2.1.1.3 Calculations and Results. The averaged laboratory results are entered into a Quattro Pro spreadsheet using a disk operating system-based personal computer. The beta ray and alpha branching ratios are entered as given in Radioactive Decay Data Tables (Kocher 1981). The activity per metric tonne of $\mathrm{N}$ Reactor fuel for each isotope is taken from ORIGEN2 Predictions of $N$ Reactor Fuel Actinide Composition (Hedengren and Goldberg 1987) and ORIGEN2 Predictions of $N$ Reactor Fuel Fission Product Composition (Hedengren and Goldberg 1985) and then entered into column four of the spreadsheet.

1Quttro is tradeanark of Dorland. 
The total activities of the alpha particle-emitting radioisotopes are then normalized to the average measured alpha particle activity, and the activity of the nonalpha particle-emitting actinides is scaled similarly. The

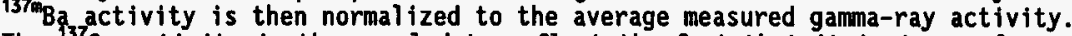
The ${ }^{137} \mathrm{Cs}$ activity is then scaled to reflect the fact that it is in secular equilibrium with ${ }^{13} \mathrm{~m} \mathrm{Ba}$.

The beta particle activities from the ${ }^{137} \mathrm{Cs}$ and from the actinides are then subtracted from the measured beta particle activity, and the remainder of the beta particle emitters are scaled such that the total beta particle activity would equal the average measured value. These values are tabulated in the column of Table B2-1 labeled "Adjusted activity."

The sixth column of the table is obtained by reducing the cesium

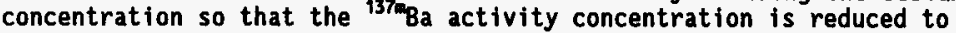
$0.286, \mu \mathrm{Ci} / \mathrm{ml}$. This 1 . The ${ }^{134} \mathrm{Cs}$, ${ }^{137} \mathrm{Cs}$, and ${ }^{137 \mathrm{Ba}}$ are affected. It is assumed that no other radioisotopes would be affected by this washing process.

The final column is obtained by multiplying the activity concentration in the previous column by the volume of the tank.

\subsubsection{Source Term Classification}

The inventory 1 isted in Table B2-1 will be transported in one shipment. It qualifies as LSA-II per 49 CFR 173.403. LSA-II classification is determined in the following manner. A liquid is defined by DOT as LSA-II if it contains less than $10^{-5} A_{2} s$ per gram. In addition, the external dose rate must not exceed $10 \mathrm{mSv} / \mathrm{h}(1 \mathrm{rem} / \mathrm{h})$ at $3 \mathrm{~m}(9.84 \mathrm{ft})$ from the unshielded material, and the payload may not exceed 100 times the $A_{2}$ quantity.

The number of $A_{2} s$ in the mixture is determined, as shown in Table B2-2, by dividing the activity of the radionuclide by the $A_{2}$ value for the radionuclide. The fraction of $A_{2} s$ is sumed to give the total $A_{2} s$ in the liquid. This sum is 56.9 , which is less than the allowable $100 \mathrm{~A}_{2} \mathrm{~s}$.

The number of $A_{2} s$ is then divided by $10^{-5}$ and the mass in grams $\left(1.75 \times 10^{7} \mathrm{~g}\right)$. The resulting number $(0.33)$ is less than 1.0 , indicating that the liquid qualifies as LSA-II.

Finally, the dose rates off of the unshielded material are calculated and are shown to be less than $10 \mathrm{mSv} / \mathrm{h}(1 \mathrm{rem} / \mathrm{h})$ at $3 \mathrm{~m}(9.84 \mathrm{ft})$ (see Part B, Section 4.0). 
Table B2-1. B Plant Organic Waste Source Term.

\begin{tabular}{|c|c|c|c|c|c|c|}
\hline Ieotope & $\begin{array}{l}\text { Alpha } \\
\text { yield }\end{array}$ & $\begin{array}{l}\text { Bets } \\
\text { yield }\end{array}$ & $\begin{array}{c}\text { CINMTIU } \\
12 x \text { fuel }\end{array}$ & $\begin{array}{c}\text { Adjusted ectivity } \\
\text { (sci/lil) }\end{array}$ & $\begin{array}{c}\text { Reduced C: } \\
\text { ectivity }\left(\Delta C 1 / L_{L}\right)\end{array}$ & $\begin{array}{c}\text { Total ectivity } \\
\text { (Ci) }\end{array}$ \\
\hline${ }^{85} x$ & & 1.000 & $5.03 \mathrm{E}+02$ & $6.49 \mathrm{E}-01$ & $6.49 \mathrm{E}-01$ & $1.13 E+01$ \\
\hline 90 & & 1.000 & $5.70 \mathrm{E}+03$ & $7.45 \varepsilon+\infty$ & $7.45 \mathrm{E}+\infty 0$ & $1.30 \mathrm{E}+02$ \\
\hline${ }^{9} \mathbf{H}_{\mathrm{Y}}$ & & 1.000 & $5.78 \mathrm{E}+03$ & $7.45 \mathrm{E}+00$ & $7.45 E+00$ & $1.30 E+02$ \\
\hline & & 1.000 & 1.71 E-01 & 2.21 E-04 & 2.21 E-04 & $3.84 E-03$ \\
\hline & & 1.000 & $1.26 \mathrm{E}+00$ & 1.62 E-03 & $1.62 E-03$ & 2.83 E-02 \\
\hline & & 1.000 & $5.23 E+01$ & 6.75 E-02 & 6.75 E-02 & $1.18 E+\infty$ \\
\hline & & 1.000 & $5.23 \mathrm{E}+01$ & 6.75 E-02 & $6.75 E-02$ & $1.18 E+\infty$ \\
\hline & & & $2.35 E+00$ & $3.04 E .03$ & $3.04 \in-03$ & $5.29 E-02$ \\
\hline & & 0.990 & $1.25 E+02$ & $1.61 E-01$ & $1.61[5-01$ & $2.80 \mathrm{E}+00$ \\
\hline & & & $3.04 E+01$ & 3.92 E-02 & 3.92 E-02 & 6.83 E-01 \\
\hline & & 1.000 & $1.27 \mathrm{E}+02$ & 1.64 E-01 & $1.21 \mathrm{E}-02$ & $2.10 E-01$ \\
\hline & & 1.000 & $7.29 \mathrm{E}+0 \mathrm{3}$ & $3.89 E+\infty$ & $2.86 \varepsilon-01$ & $4.98 E+00$ \\
\hline & & & $6.90 E+03$ & $3.68 E+00$ & $2.71 E-01$ & $4.71 E+00$ \\
\hline & & 1.015 & $2.79 E+01$ & 3.60 E-02 & 3.60 E-02 & $6.26 E-01$ \\
\hline & & 1.000 & $2.79 E+01$ & 3.60 E-02 & 3.60 E-02 & $6.26 E-01$ \\
\hline & & & $3.35 E-01$ & 4.32 E-04 & 4.32 E-04 & $7.52 E-03$ \\
\hline & & 1.000 & $1.96 E+03$ & $2.52 E+00$ & $2.52 E+00$ & $4.39 E+01$ \\
\hline & & 1.000 & $8.95 E+01$ & $1.15 E-01$ & $1.15 \mathrm{E}-01$ & $2.01 E+00$ \\
\hline & & 0.710 & 6.51 E-01 & 8.41 E- 04 & $8.41 E-04$ & 1.46 E-02 \\
\hline & & 1.000 & $8.80 E+01$ & $1.16 E-01$ & 1.14 E-01 & $1.98 E+00$ \\
\hline & & 1.010 & $3.48 \mathrm{E}+01$ & $4.49 E-02$ & $4.49 E-02$ & 7.82 E-01 \\
\hline & & 1.001 & 3.32 E-01 & $1.52 E+06$ & 1.52 E-06 & $2.65 E-05$ \\
\hline $234 \mathrm{Th}$ & & 1.000 & 3.32 E-01 & $1.52 \varepsilon-06$ & $1.52 \mathrm{E}-06$ & $2.65 E-05$ \\
\hline 23 & 1.000 & & $4.23 \varepsilon-01$ & $1.9 E-06$ & $1.94 E-06$ & $3.38 E-05$ \\
\hline $237 v$ & & 1.010 & 1.09 E-01 & 5.00 E-07 & 5.00 E-07 & 8.71 E-06 \\
\hline 2 & 1.002 & & 3.32 E-01 & $1.52 E-06$ & $1.52 E-06$ & 2.65 E-05 \\
\hline & 1.000 & & $4.77 \mathrm{E}+01$ & 2.19 E-04 & 2.19 E-04 & $3.81 E-03$ \\
\hline 235 & 0.999 & & $1.10 \mathrm{E}+02$ & $5.05 \mathrm{E}-04$ & 5.05 E-04 & $8.79 E-03$ \\
\hline 240 & 1.000 & & $5.82 \mathrm{E}+01$ & 2.67 E-04 & $2.67 \varepsilon-04$ & $4.65 E-03$ \\
\hline 24 & 0.000 & 1.000 & $4.45 E+03$ & 2.04 E-02 & 2.04 E-02 & $3.55 E-01$ \\
\hline 261 & 1.000 & & $9.29 E+01$ & 6.26 E-04 & $4.26 \mathrm{E}-04$ & $7.42 \mathrm{E}-03$ \\
\hline & 0.005 & & $1.08 E-01$ & 4.96 E-07 & 4.96 E-07 & 8.64 E-06 \\
\hline $242 \sqrt{\mathrm{m}}$ & & 0.827 & 1.08 E-01 & 4.93 E-07 & $4.93 E-07$ & $8.59 E-06$ \\
\hline \multicolumn{6}{|c|}{ Total ectivity } & $3.37 \mathrm{E}+02$ \\
\hline \multicolumn{2}{|c|}{ Total bete } & \multicolumn{2}{|c|}{$2.64 \mathrm{E}+04 \mathrm{CI}$} & $2.28 \mathrm{E}+01$ & $1.90 E+01$ & $3.32 \mathrm{E}+02$ \\
\hline \multicolumn{2}{|c|}{ Total alphs } & \multicolumn{2}{|c|}{$3.10 \mathrm{E}+02 \mathrm{Ci}$} & 1.42 E-03 & $1.42 E-03$ & $2.67 \varepsilon-02$ \\
\hline
\end{tabular}

MTIU = Metric tome of initial uranive. 
Table B2-2. Low Specific Activity Determination.

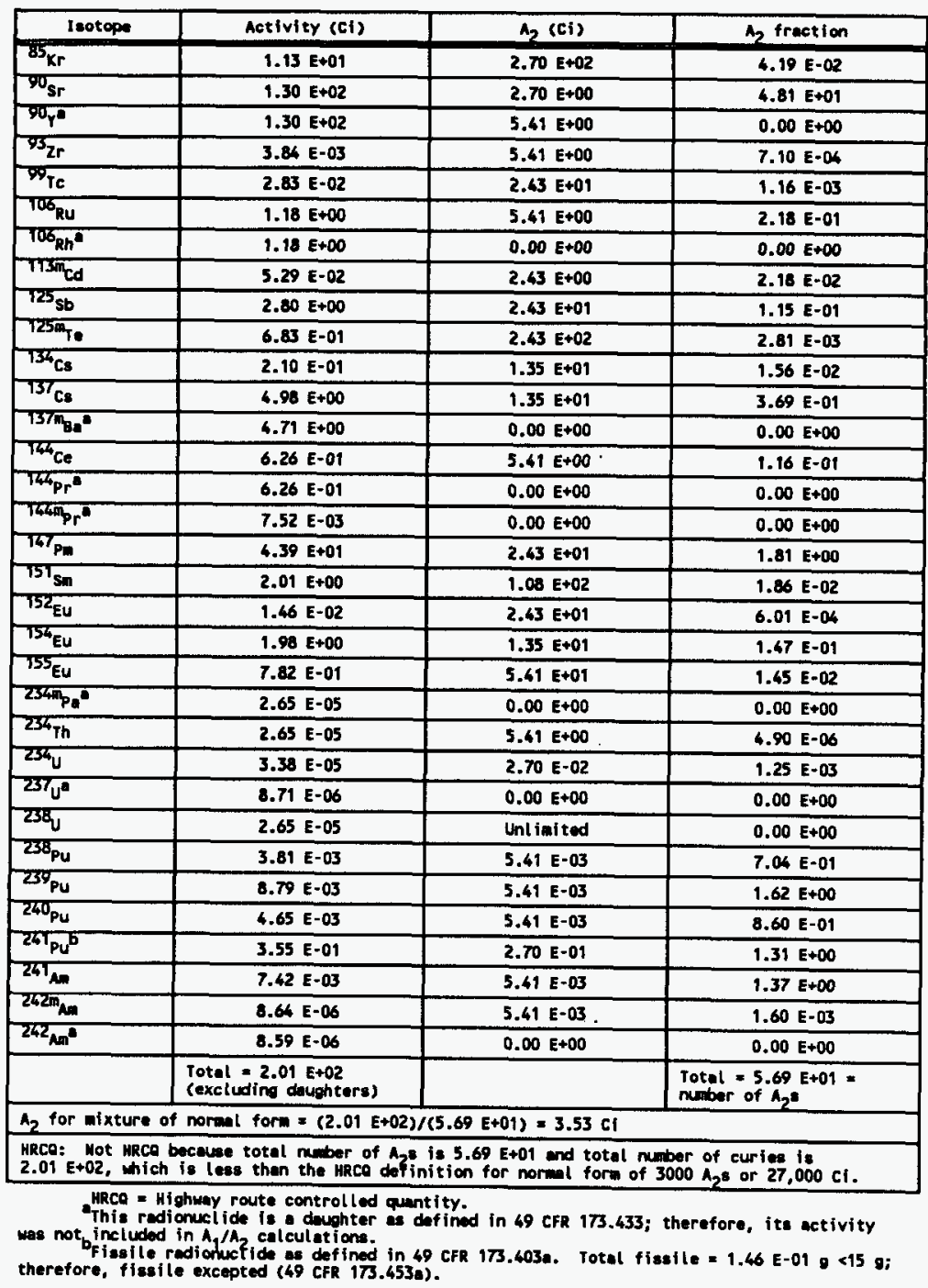


WHC-SD-TP-SEP-050 Rev. 0

\subsection{RESTRICTIONS}

The special transfer requirements of Part A, Section 4.3 , shall be met.

\subsection{SIZE AND WEIGHT}

The liquid payload is limited to a maximum weight of $17,500 \mathrm{~kg}$ $(38,581 \mathrm{lb})$. This weight is calculated on the conservative assumptions of $17,500 \mathrm{~L}(4,623 \mathrm{gal})$ and a specific gravity of 1 .

\subsection{CoNClusions}

The organic waste is acceptable for transport in the tank provided the requirements of this SEP are met.

\subsection{REFERENCES}

49 CFR 173, 1996, "Shippers--General Requirements for Shipments and Packagings," Code of Federal Regulations, as amended.

Enge1, R. L., J. Greenborg, and M. M. Hendrickson, 1966, ISOSHLD - A Computer Code for General Purpose Isotope Shielding Analysis, BNWL-236, rev. 1.98, Battelle-Northwest Laboratories, Richland, Washington. June 1966.

Goldberg, H. J., 1996, Source Term for the B-P7ant Organic Waste, WHC-SD-WM-CN-029, Rev. 0, Westinghouse Hanford Company, Richland, Washington.

Hedengren, D. C., and H. J. Goldberg, 1985, ORIGEN 2 Predictions of $N$ Reactor Fuel Fission Product Composition, SD-CP-TI-177, Westinghouse Hanford Company, Richland, Washington.

Hedengren, D. C., and H. J. Goldberg, 1987, ORIGEN2 Predictions of $N$ Reactor Fuel Actinide Composition, SD-CP-TI-105, Westinghouse Hanford Company, Richl and, Washington.

Kocher, D. C., 1981, Radioactive Decay Data Tables, DOE/TIC-11026, Technical Information Center, U.S. Department of Energy, Oak Ridge, Tennessee.

Rittmann, P. D., 1995, ISO-PC Version 1.98 - User's Guide, WHC-SD-WM-UM-030, Rev. 0, Westinghouse Hanford Company, Richland, Washington.

Simmons, G. L., J. J. Regimbal, J. Greenborg, E. L. Kelly, Jr., and H. H. van Tuyl, 1967, ISOSHLD-II: Code Revision to Include Calculation of Dose Rate from Shie7ded Bremsstrahlung Sources, BNWL-236, Supplement 1, Battelle-Northwest Laboratories, Richland, Washington. 
WHC-SD-TP-SEP-050 Rev. 0

This page intentionally left blank. 
WHC-SD-TP-SEP-050 Rev. 0

\subsection{CONTAINMENT EVALUATION}

\subsection{INTRODUCTION}

The purpose of this evaluation is to determine the ability of the B Plant organic tank to maintain it contents under onsite normal transfer conditions.

\subsection{CONTAINMENT SOURCE SPECIFICATION}

The authorized payload is described in Part B, Section 2.0.

\subsection{NORMAL TRANSFER CONDITIONS}

\subsubsection{Conditions To Be Evaluated}

The primary condition to be evaluated for normal transfer conditions is structural integrity.

\subsubsection{Release Acceptance Criteria}

The tank was certified for offsite shipping of LSA material. Because this payload is also LSA, the tank is considered to be acceptable as long as its structural capabilities are not compromised by the modifications. The modifications are described in Part A, Section 2.1 .

\subsection{CONTAINHENT EVALUATION AND CONCLUSIONS}

The modifications are described in Part A, Section 2.1. The spilldam is not part of the containment boundary and does not provide structural integrity. Therefore, adding the vents or cover to the spilidam cannot affect containment. The filter for the air inlet valve bolts to the downstream side of the existing valve. Because this valve is closed during shipment, adding the filter does not affect containment. Adding the 12.7-cm- (5-in.-) long extension to the inside of the air inlet valve does not affect the structural integrity of the valve and therefore does not affect containment. Finally, replacing the pressure vent assembly with a valve and filter does not affect containment; the valve and filter are identical to those used on the air inlet valve, and the valve is closed during the shipment. The tank containment is considered to be adequate based on the above evaluations. 
WHC-SD-TP-SEP-050 Rev. 0

This page intentionally left blank. 
WHC-SD-TP-SEP-050 Rev. 0

\subsection{SHIELDING EVALUATION}

\subsection{INTRODUCTION}

This shielding evaluation supports the shipment of liquid organic waste in a tank truck. The tank truck will be used to transport the organic waste from the load-out station of B Plant to a waste interim storage area.

The contents have been classified as LSA-II. LSA-II material must have an exterior dose rate from the unshielded surface of less than $10 \mathrm{mSv} / \mathrm{h}$ $(1,000 \mathrm{mrem} / \mathrm{h})$ at $3.0 \mathrm{~m}(9.8 \mathrm{ft})$. Other 1 imits require that norma 1 shipments are less than $2 \mathrm{mSv} / \mathrm{h}(200 \mathrm{mrem} / \mathrm{h})$ on the surface of the tank, $0.1 \mathrm{mSv} / \mathrm{h}$ $(10 \mathrm{mrem} / \mathrm{h})$ at $2 \mathrm{~m}(6.56 \mathrm{ft})$, and $0.05 \mathrm{mSv} / \mathrm{h}(5 \mathrm{mrem} / \mathrm{h})$ at the driver's location or any occupied space provided that the driver or worker is a qualified Hanford Site radiological worker. To provide protection, given any particular circumstance, administrative controls are enforced (as specified in Part A, Section 4.3) to guarantee that during transportation no exposure to the public will occur and that ALARA procedures will be followed to guarantee the safety of the workers.

\subsection{DIRECT RADIATION SOURCE SPECIFICATION}

\subsubsection{Photon Source}

The source term for the shipment of the organic waste is developed in Part B, Section 2.0, and is 1isted in Table B4-1.

\subsubsection{Beta Particle Source}

The wall of the tank is $0.8 \mathrm{~cm}(5 / 16 \mathrm{in}$.) thick. This thickness is greater than the range of the most energetic beta particle emanating from the waste (the $2.2839 \mathrm{MeV}$ beta particle from ${ }^{90} \mathrm{Y}$ ). Thus, doses from the direct interaction of a receptor with beta particles will be negligible, at most.

\subsubsection{Neutron Source}

The concentration of neutron-emitting radionuclides indicates that the neutron dose will be negligible.

\subsection{SUNMARY OF SHIELDING PROPERTIES OF MATERIALS}

The computer code ISOSHLD (Engel et al. 1966, Simmons et al. 1956, Rittmann 1995) is used on a desktop disk operating system-based personal computer. The attenuation, buildup, and Bremsstrahlung properties of the materials chosen are contained therein. The problem-specific description of the calculational model is described in Part B, Section 4.4.3 
WHC-SD-TP-SEP-050 Rev. 0

Table B4-1. B Plant Organic Waste Source Term.

\begin{tabular}{|l|l|l|c|}
\hline \multicolumn{1}{|c|}{ Isotope } & Total activity (Ci) & \multicolumn{1}{|c|}{ Isotope } & Total activity (Ci) \\
\hline${ }^{85} \mathrm{Kr}$ & $1.13 \mathrm{E}+01$ & ${ }^{151} \mathrm{Sm}$ & $2.01 \mathrm{E}+00$ \\
\hline${ }^{90} \mathrm{Sr}$ & $1.30 \mathrm{E}+02$ & ${ }^{152} \mathrm{Eu}$ & $1.46 \mathrm{E}-02$ \\
\hline${ }^{90} \mathrm{Y}$ & $1.30 \mathrm{E}+02$ & ${ }^{154} \mathrm{Eu}$ & $1.98 \mathrm{E}+00$ \\
\hline${ }^{93} \mathrm{Zr}$ & $3.84 \mathrm{E}-03$ & ${ }^{155} \mathrm{Eu}$ & $7.82 \mathrm{E}-01$ \\
\hline${ }^{99} \mathrm{TC}$ & $2.83 \mathrm{E}-02$ & ${ }^{234} \mathrm{~Pa}$ & $2.65 \mathrm{E}-05$ \\
\hline${ }^{106} \mathrm{Ru}$ & $1.18 \mathrm{E}+00$ & ${ }^{234} \mathrm{Th}$ & $2.65 \mathrm{E}-05$ \\
\hline${ }^{106} \mathrm{Rh}$ & $1.18 \mathrm{E}+00$ & ${ }^{234} \mathrm{U}$ & $3.38 \mathrm{E}-05$ \\
\hline${ }^{113} \mathrm{Cd}$ & $5.29 \mathrm{E}-02$ & ${ }^{237} \mathrm{U}$ & $8.71 \mathrm{E}-06$ \\
\hline${ }^{125} \mathrm{Sb}$ & $2.80 \mathrm{E}+00$ & ${ }^{238} \mathrm{U}$ & $2.65 \mathrm{E}-05$ \\
\hline${ }^{125 m} \mathrm{Te}$ & $6.83 \mathrm{E}-01$ & ${ }^{238} \mathrm{Pu}$ & $3.81 \mathrm{E}-03$ \\
\hline${ }^{134} \mathrm{Cs}$ & $2.10 \mathrm{E}-01$ & ${ }^{239} \mathrm{Pu}$ & $8.79 \mathrm{E}-03$ \\
\hline${ }^{137} \mathrm{Cs}$ & $4.98 \mathrm{E}+00$ & ${ }^{240} \mathrm{Pu}$ & $4.65 \mathrm{E}-03$ \\
\hline${ }^{137 m} \mathrm{Ba}$ & $4.71 \mathrm{E}+00$ & ${ }^{261} \mathrm{Pu}$ & $3.55 \mathrm{E}-01$ \\
\hline${ }^{144} \mathrm{Ce}$ & $6.26 \mathrm{E}-01$ & ${ }^{249} \mathrm{Am}$ & $7.42 \mathrm{E}-03$ \\
\hline${ }^{144} \mathrm{Pr}$ & $6.26 \mathrm{E}-01$ & ${ }^{242 m} \mathrm{Am}$ & $8.64 \mathrm{E}-06$ \\
\hline${ }^{144 m} \mathrm{Pr}$ & $7.52 \mathrm{E}-03$ & ${ }^{242} \mathrm{Am}$ & $8.59 \mathrm{E}-06$ \\
\hline${ }^{147} \mathrm{Pm}$ & $4.39 \mathrm{E}+01$ & & \\
\hline
\end{tabular}

\subsection{MORMAL TRANSFER CONDITIONS}

\subsubsection{Conditions To Be Evaluated}

The anterior-to-posterior effective dose equivalent is calculated at contact and at distances of $2 \mathrm{~m}(6.56 \mathrm{ft})$ and $6 \mathrm{~m}(19.69 \mathrm{ft})$ from the surface of the container. These calculations are carried out for distances off the side of the container as well as for distances off the end face. For purposes of LSA classification, the dose is also calculated at $3 \mathrm{~m}(9.84 \mathrm{ft})$, assuming no shielding is present.

\subsubsection{Acceptance Criteria}

Transportation safety requires dose rate 1 imits of $200 \mathrm{mrem} / \mathrm{h}$ on the surface of the vehicle (including the top and underside), $10 \mathrm{mrem} / \mathrm{h}$ at any point $2 \mathrm{~m}(6.56 \mathrm{ft})$ from the outer lateral surfaces of the vehicle (excluding 
WHC-SD-TP-SEP-050 Rev. 0

the top and underside of the vehicle), and $5 \mathrm{mrem} / \mathrm{h}$ at any normally occupied space (taken to be $6 \mathrm{~m}[19.69 \mathrm{ft}]$ ) provided the space is occupled by a qualified Hanford Site radiological worker. In addition, LSA-II requires that the dose rate be less than $10 \mathrm{mSv} / \mathrm{h}(1,000 \mathrm{mrem} / \mathrm{h})$ at $3 \mathrm{~m}(9.84 \mathrm{ft})$ from the unshielded material. To provide protection, administrative controls are enforced to guarantee no exposure to the public, and ALARA procedures will be followed to protect the worker (Part A, Section 4.3).

\subsubsection{Shielding Model}

The computer code ISOSHLD (Engel et al. 1966, Simmons et al. 1956, Rittmann 1995) is used on a desktop disk operating system-based personal computer. This code performs a point kernel integration over the source region and sums the contributions of each of the point kernels to the dose at a point detector. The program also accounts for Bremsstrahlung produced by B-particles.

The nitric acid tank, manufactured by Brenner Tank, Incorporated, is made of steel and has a rated volume of $17,500 \mathrm{~L}(4,623 \mathrm{gal})$. It is in the shape of a right cylinder with rounded ends. For the purpose of this analysis, the model has flat ends. The dimensions used in the analysis are presented in Table B4-2.

Table B4-2. Tank Dimensions Used in Calculations.

\begin{tabular}{|l|l|l|}
\cline { 2 - 3 } \multicolumn{1}{c|}{} & \multicolumn{1}{c|}{ SI units } & \multicolumn{1}{c|}{ English units } \\
\hline Inner diameter & $199.1 \mathrm{~cm}$ & $78.38 \mathrm{in}$. \\
\hline Length & $559.8 \mathrm{~cm}$ & $220.4 \mathrm{in}$. \\
\hline Volume & $17,413 \mathrm{~L}$ & $4,600 \mathrm{gal}$ \\
\hline Wall thickness & $0.8 \mathrm{~cm}$ & $5 / 16 \mathrm{in}$. \\
\hline
\end{tabular}

81 = Standard international systen of units.

The steel density is assumed to be $7.85 \mathrm{~g} / \mathrm{cm}^{3}$. This is conservative because various types of stainless steel can be denser than this. The density of the waste material is assumed to be $0.85 \mathrm{~g} / \mathrm{cm}^{3}$.

\subsection{SHIELDING CALCULATIONS}

The ISOSHLD results are as shown in Table B4-3. 
Table B4-3. Effective Dose Equivalent.

\begin{tabular}{|l|l|l|l|}
\cline { 2 - 4 } \multicolumn{1}{c|}{} & $\begin{array}{l}\text { Center of side } \\
\mathrm{mSv} / \mathrm{h}(\mathrm{mrem} / \mathrm{h})\end{array}$ & $\begin{array}{l}\text { Center of end } \\
\mathrm{mSv} / \mathrm{h}(\mathrm{mrem} / \mathrm{h})\end{array}$ & $\begin{array}{c}\text { Limits } \\
\mathrm{mSv} / \mathrm{h}(\mathrm{mrem} / \mathrm{h})\end{array}$ \\
\hline Contact & $1.4(140)$ & $0.72(72)$ & $2.0(200)$ \\
\hline $2 \mathrm{~m}(6.56 \mathrm{ft})$ from surface & $0.31(31)^{*}$ & $0.20(20)^{*}$ & $0.10(10)$ \\
\hline $\begin{array}{l}6 \mathrm{~m}(19.69 \mathrm{ft}) \text { from surface } \\
\text { (driver's location) }\end{array}$ & NA & $0.046(4.6)$ & $0.05(5)$ \\
\hline $\begin{array}{l}3 \mathrm{~m}(9.84 \mathrm{ft}) \text { from } \\
\text { unshieided material }\end{array}$ & $0.45(45)$ & $0.27(27)$ & $1.0(1000)$ \\
\hline
\end{tabular}

ALARA = As low as reasonably achievable.

Adhinistrative controls are enforced to gurantee no exposure to the

public, and ALAMA procedures will be followd to protect the worker (Pert A, section 4.3).

The source term used in the analysis has a high degree of uncertainty, but is expected to be the bounding case. Therefore, administrative controis are enforced to guarantee the safety of the worker and no exposure to the public. These controls are specified in Part A, Section 4.3.

\subsection{REFERENCES}

49 CFR 173.401, 1994, "Shippers--General Requirements for Shipments and Packagings," .401, "Scope," Code of Federal Regulations, as amended.

49 CFR 173.441, 1994, "Shippers--General Requirements for Shipments and Packagings," .441, "Radiation Level Limitations," Code of Federal Regulations, as amended.

ANSI, 1991, Neutron and Gamma-Ray Fluence-to-Dose Factors, ANSI/ANS-6.1.1-1991, American National Standards Institute, New York, New York.

Browne, E., R. B. Firestone, and V. S. Shirley, 1986, Table of Radioactive I sotopes, John Wiley \& Sons, New York, New York.

Enge1, R. L., J. Greenborg, and M. M. Hendrickson, 1966, ISOSHLD - A Computer Code for General Purpose Isotope Shielding Analysis, BNWL-236, Rev. 1.98, Battelle-Northwest Laboratories, Richland, Washington, June.

Goldberg, H. J., 1996, Source Tern for the B-Plant Organic Waste, WHC-SD-WM-CN-029, Rev. 0, Westinghouse Hanford Company, Richland, Washington.

Hedengren, D. C., and H. J. Goldberg, 1985, ORIGEN2 Predictions of $N$ Reactor Fuel Fission Product Composition, SD-CP-TI-117, Westinghouse Hanford Company, Richland, Washington. 
Hedengren, D. C., and H. J. Goldberg, 1987, ORIGEN2 Predictions of N Reactor Fue7 Actinide Composition, SD-CP-TI-105, Westinghouse Hanford Company, Richl and, Washington.

Jaeger, R. G., et al., ed., 1968, Engineering Compendium on Radiation Shielding, Vol. 1, Springer-Verlag, New York, New York.

Kocher, D. C., 1981, Radioactive Decay Data Tables, DOE/TIC-11026, Technical Information Center, Department of Energy, Oak Ridge, Tennessee.

Rittmann, P. D., 1995, ISO-PC Version 1.98 - User's Guide, WHC-SD-WM-UM-030, Rev. 0, Westinghouse Hanford Company, Richland, Washington, May 1995.

Simmons, G. L., J. J. Regimbal, J. Greenborg, E. L. Kelly, Jr., and H. H. van Tuyl, 1967, ISOSHLD-II: Code Revision to Include Calculation of Dose Rate from Shielded Bremsstrahlung Sources, BNWL-236, Supplement 1, Battelle-Northwest Laboratories, Richland, Washington. 
WHC-SD-TP-SEP-050 Rev. 0

\subsection{APPENDICES}

\subsubsection{Checkl ist for Independent Technical Review}

CHECKLIST FOR IWOEPENOEIT TECHICAL REYIEN

DOCUMENT REVIEWED

MUMBER: $8: 430-H .3 G-96-011$

TITLE: SHIELDING ANALYSES FOR THE SHIPHENT OF B-PLANT ORGANIC WASTE AUTHOR(s): H. J.Goldbera

I. Method(s) of Review

(x) Input data checked for accuracy

( ) Independent calculation parformed () Hand calculation

() Alternate computer code:

( ) Compartson to experiment or previous results

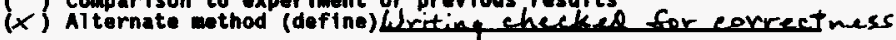

II. Checklist (etther check or enter NA If not applied)

(NA) Task completely defined

(W/A) Activity consistent with task specification

(WA) Necessary assumptions explicitiy stated and supported

(x) Resources properly identified and referenced

(x) Resource documentation appropriate for this application

(x) Input data explicitly stated

(X) Input data verified to be consistent with original source

(WN) Geometric model adequate representation of actual geometry

(WA Material properties appropriate and reasonable

(NA) Mathematical derivations checked including dienensional consistency

(WN Hand calculations checked for errors

(NA) Assumptions explicitly stated and justified

(NA Computer software appropriate for task and used within range of validity

(WA) Use of resource outside range of established validity is justified

(NA) Software runstreams correct and consistent with results

(WA) Software output consistent with input.

(Wh Results consistent with applicable previous experimental or analytical findings

(WA) Results and conclusions address 911 points and are consistent

wth task requirements and/or established 1 imits or criterla

(WA) Conclusions consistent with analytical results and established jimits

(NA) Uncertainty assessment appropriate and reasonable

(I) Other (define)

III. Comments :

IV.

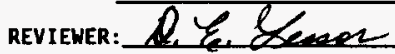

DATE: $6-25-96$ 
DOCUMENT REVIEWED

NUMBER: 8M730-HJG-96-011

TITLE: SHIELDING AMALYSES FOR THE SHIPMENT OF B-PLAMI ORGANIC MASTE

AUTHOR(s): H, l, Goldberg

I. Method(s) of Review

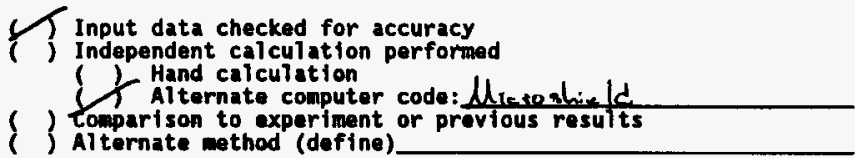

II. Checklist (either check or enter MA if not applied)

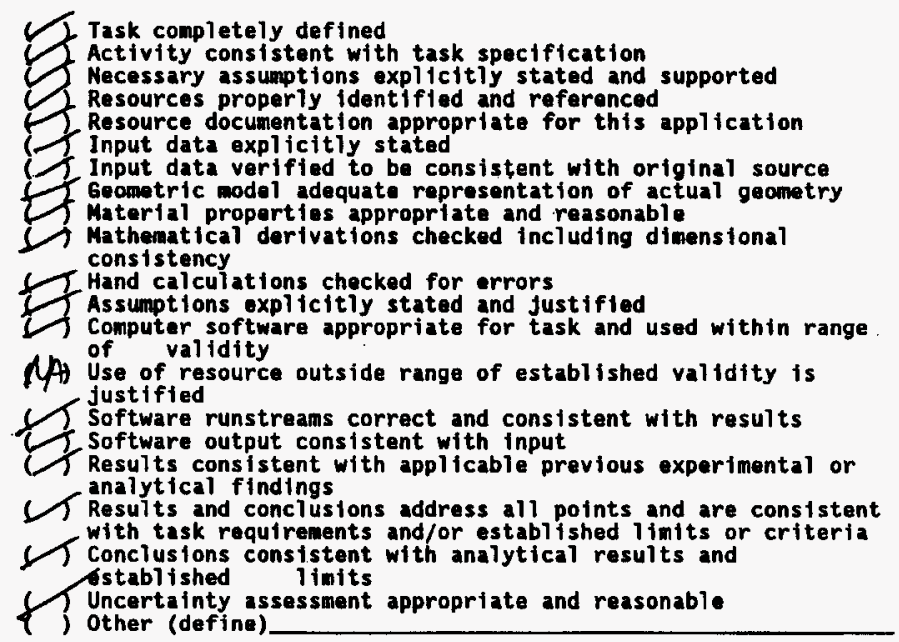

III. Comments :

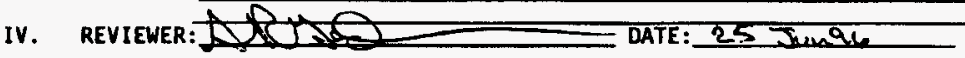


WHC-SD-TP-SEP-050 Rev. 0

\subsubsection{Computer Input Files}

Input File (O: UISOSHLOINPUTV_PLAT.) is shom below:

0 2 B-PLANT ORGNIC MASTE SOURCE TERA

POINT SOURCE DOSE AT ONE METER

\&INPUT NEXT $=1$, IEEOH=3, MSHLD $=1$, JBUF $=1$, IPRNT $=0$,

$X=100$., $T(1)=0.02$, ouni $T=1$, opí Iou $=1$,

ICONC $=0$, SFACT $=17.413$,

WEIGHT(055) $=6.5 E-01$, VEI GHT(082) $=7.5 E+00$, WEIGHT $(084)=7.5 E+00$, WEIGHT(102)=2.2E-04, WEICHT (141)=1.6E-03, WEICHT(170)=6.8E-02, MEIGHT(172)=6.8E-02, WEIGHT (206)=3.0E-03, MEIEHT(269)=1.6E-01. WEIGHT(2TO)=3.9E-02, WEIEHT(319)=1.2E-02, WEICHT(335)=2.9E-01, WEIGHT(336)=2.7E-01, WEIGHT $(376)=3.6 E-02$, VEIGHT $(377)=3.6 E-02$, WEIGHT (388)-2.5E+00, VEIGHT (403)=1.2E-01, VEICHT (403)=8.4E-04, WEIGHT(415)=1.1E-01, WEICHT(418)-4.5E-02, VEIAHT(533)=1.5E-06, WEIGHT (530)-1.5E-06, WEI EHT (520)=1.9E-06, WEIEHT (491)=5.0E-07, WEIGHT(526)=1.5E-06, WEIEHT(492) $=2.2 E-04$, WEICHT(493)=5. 1E-04. WEIGHT (494)=2.7E-04, VEIGUT(495) $=2.0 E-02$, VEIEHT (496) $=4.3 E-04$, WEIGHT(498)=5.0E-07, WICHT(499)=4.9E-07, ह

1 SOURCE 91.2

TANK SOURCE DOSE AT CONTACT - SIDE - (CHECK FOR MEAN FREE PATM) \&INPUT MEXT 1 1, IGEONM7, NSHLDE2, JBUF $=2$, IPRWT $=0$,

$X=100.8, T(1)=99.5, T(2)=0.794, S L T H=559.84, Y=279.92$, I CONC=1, SFACT=1, DUNIT=1, OPTION $=1$, UPSI $=15$, MTUETA 19 , DELR=2.

WEIGHT $(055)=6.5 E-01$, LEIGHT $(082)=7.5 E+00$, LEIGHT $(084)=7.5 E+00$, VEIGHT $(102)=2.2 E-04$, VEIGHT $(141)=1.6 E-03$, VEICHT $(170)=6.8 E-02$, WEIGHT(172) $=6.8 E-02$, WEIGHT(206)=3.0E-03, WEIGHT(269)=1.6E-01, WEIGHT (270)=3.9E-02, VEIGHT (319)=1.2E-02, VEIGHT (335)=2.9E-01, WEIGHT (336)=2.7E-01, WeICHT (376)=3.6E-02, VEICUT $(377)=3.6 E-02$, WEIGHT (388)=2.5E+00, WEIGHT (403)=1.2E-01, VEIGHT (408)=8.4E-04, WEIGNT (415)=1.1E-01, WEICNT (418) $-4.5 E-02$, VEIGNT (533)=1.5E-06, WEIGHT (530)=1.5E-06, WEI GHT (520)=1.9E-06, MEIGHT(491)=5.0E-07, WEIGHT(526)=1.5E-06, WEIGHT(492)=2.2E-06, WEIGHT(493)=5.1E-06, WEIGHT (494) $=2$.7E-04, MEIGNT (495)=2.0E-02, MEIGHT (496) $=6.3 E-04$, WEIGHT (498) $=5.0 E-07$, WEIGHT (499) $=4.9 E-07$, E SOURCE 20.85

1 STEEL 9 7.85

TANK SOURCE DOSE AT ONE METER - SIDE

\&INPUT NEXT $=4$, OPT ION $=0, X=200 ., 2$

TAHK SOURCE DOSE AT TWO METERS - SIDE

RINPUT NEXT $=4, x=300 .$,

TAMK SOURCE DOSE AT SIX́ METERS - SIDE

QINPUT MEXT $=4, X=700$., 
TANK SOUACE DOSE AT CONTACT - EID - (CHECK FOR MEAM FREE PATH) RINPUT NEXT $=1$, ICEON 7, MSHLD $=2$, JOUF $=2$, IPRNT $=0$, $X=561.2, T(1)=559.84, T(2)=0.794,8 L T H=99.5$, ICONC=1, SFACT=1., DUNIT=1, OPTION =1, MTHETA=19, DELR=2.

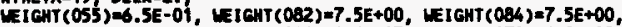
MEIGHT(102)=2.2E-04, WEICHT(161)=1.6E-03, WEIGHT(170)=6.8E-02, MEIGHT(172)-6.8E-02, WEICHT(206)=3.0E-05, WEIGHT(269)=1.6E-01, HEIGHT(270)=3.9E-02, WEICHT(319)=1.2E-02, VEIGHT(335)=2.9E-01, WEIGHT(336)=2.7E-01, vEICHT(376)=3.6E-02, MIGHT(377)=3.6E-02, LEIGHT(388)=2.5E+00, VEICHT (403)=1.2E-01, MICHT(408)=8.4E-04, VEIGHT(415)-1.1E-01, WEI C्AT(418)-4.5E-02, VEIEHT(533)=1.5E-06, WEIGHT(530)=1.5E-06, VEICHT(520)=1.9E-06, VEIEHT(491)=5.0E-07, WEIGHT (526)=1.5E-06, WEIGHT(492)=2.2E-04, WEIGHT (493)=5. 1E-04, VEI CHT (494)=2.7E-04, VIICKT $(495)=2.0 E-02$, VEICHT $(496)=4.3 E-04$,

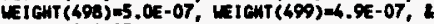
SOURCE 20.85

1 STEEL 9 7.85

TAUK SOURCE DOEE AT OUE WETER - EWD

LIWPUT WEXTh, OPTIOW=0, X=660., 2

TANK SOURCE DOSE AT TWO METERS - EW

LINPUT NEXT $4, x=760$. ,

TAMK SOURCE DOEE AT SIX METERS - EMD

BINPUT MEXT $=4, X=1160$.,

DATS ALL PHOLOUESHIIIII!

HIMPUT MEXT $=6,2$

Input File (D: IISOSHLDYIAPUTV_PLANT.) is show below:

O 2 B-PLANT ORGNIC MASTE SOURCE TERH

POINT SOURCE DOSE AT OUE METER

BINPUT MEXT=1, IEECN=3, MSHLD-1, JEUF=1, IPANT=0,

$X=100 ., T(1)=0.02$, DUNIT=1, OPTION =1,

ICONC $=0$, SFACT $=17.413$,

WEICHT (055) $=6.5 E-01$, VEICHT $(082)=7.5 E+00$, WEIGHT (084) $=7.5 E+00$ WEIGHT(102)=2.2E-04, VEIGHT(141)=1.6E-03, MEIGHT(170) $-6.8 E-02$, WEIGHT(172)=6.8E-02, VEICHT(206)=3.0E-03, MEIGHT(269)=1.6E-01, WEICHT (270)=3.9E-02, MEICHT (319)=1.2E-02, MEIGHT(335)=2.9E-01, WEIGHT (336)=2.7E-09, WEICHT (376)=3.6E-02, MEIGHT(377) =3.6E-02, WEI GHT (388)=2.5E+00, WEICHT (603)=1.2E-01, WEIGHT(408)=8.4E-06, MEIGHT(415)=1.1E-01, MEIGUT(618)=6.5E-02, MEIGHT(533)=1.5E-06, WEIGHT(530)=1.5E-06, WEICHT (520)=1.9E-06, MEIGHT(491)=5.0E-07, MEICHT (526)=1.5E-06; MEICHT(492)=2.2E-06, MEIGHT(493)=5.1E-04, WEICHT (494)=2.7E-04, WEICHT (495)=2.0E-02, VEIGHT(496)=4.3E-04, weIGHT (498)=5.0E-07, UEIEUT (499) $=4.92-07$, \&

1 sounce 91.2

TANK SOURCE DOSE AT CONTACT - SIDE - (CNECK FOR MEAN FREE PATH)

QINPUT NEXT=1, ICEON=7, MSULDE2, JEUF $=2$, IPRNT $=0$,

$X=100.8, T(1)=99.5, T(2)=0.794, s L T H=559.84, Y=279.92$,

I CONC=1, SFACT=1., DUNIT=1, OPTION =1,

MPSI=15, MTHETA=19, DELR=2.

MEIGHT $(055)=6.5 E-01$, WEIGHT $(082)=7.5 E+00$, MEIGHT $(084)=7.5 E+00$, WEIGHT (102)=2.2E-04, WEIGUT (161)=1.6E-03, MEIGHT (170) $=6.8 E-02$, WEIGHT(172)-6.0E-02; MEIGHT(206)=3.0E-03; WEIGNT(269)=1.6E-01, WEIGHT (270) =3.9E-02, WEI CHT (319)=1.2E-02, WEIGHT(335)=2.9E-01, WEIGKT (336)=2.7E-01, WEIGUT (376)-3.6E-02, UEIGUT (377) =3.6E-02, WEIGHT (388) $=2.5 E+00$, WEI CHT (403)-1.2E-01, MEICHT (408) $=6.4 E-04$ VEIGHT (415)=1.1E-01, VEICHT (498)=4.5E-02, WEIGHT (533)=1.5E-06 WEIGHT (530)=1.5E-06, WEIGHT (520)=1.9E-06, VEIGHT(491)=5.0E-07, WEIGHT(526)=1.5E-06, WEI CHT (492)-2.2E-04, WEIEHT(493) $=5$. TE-04, WEIGHT(494)=2.7E-04, WEIGHT (495)=2.0E-02, WEIENT (496)=4.3E-04, WEIGHT (498) $=5.0 E-07$, WEIOHT (499)=4.9E-07, \& source 20.85

1 STEEL 9

7.85

TANK SOURCE DOSE AT ONE METER - SIDE

BINPUT MEXT $=4$, OPTION=0, $X=200$. \&

TANK SOURCE DOSE AT TWO METERS - SIDE

IINPUT MEXT $=4, X=300 .$,

TANK SOURCE DOSE AT SIX METERS - SIDE RINPUT NEXT $=4, X=700$., \&

TANK SOURCE DOSE AT CONTACT - ENO - (CHECK FOR MEAN FREE PATH) 8INPUT MEXT $=1$, IGEOM=7, NSHLD 2 , JWUF $=2$, IPRMT $=0$, $X=561.2, T(1)=559.84, T(2)=0.7 \%$, sLTH=99.5, 
WHC-SD-TP-SEP-050 R'ev. 0

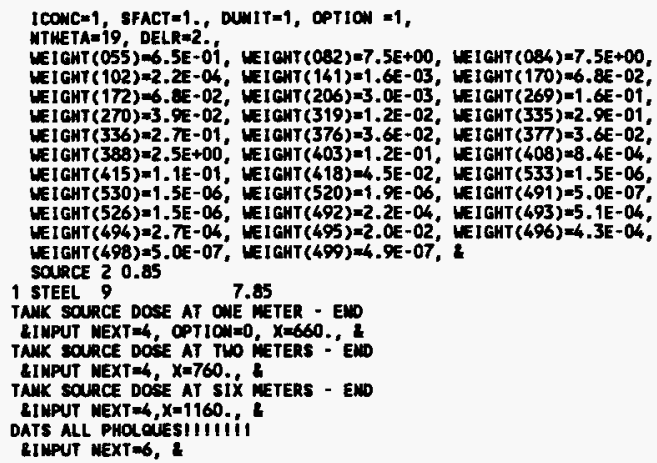




\subsection{CRITICALITY}

The definition of fissile materials in 49 CFR 173.401 lists the following isotopes: ${ }^{233} \mathrm{U},{ }^{235} \mathrm{U},{ }^{238} \mathrm{Pu},{ }^{239} \mathrm{Pu}$, and $241 \mathrm{Pu}$. The plutonium isotope inyentory to be shipped is taken from Table B2-1. However, the activities of ${ }^{233} \mathrm{U}$ and ${ }^{235} \mathrm{U}$ are below the cutoff level used in the development of the source as discussed in Part B, Section 2.0, and are therefore not reported in that section. The activities of these two isotopes shown in Table B5-1 are therefore developed using the same methodology as discussed in Part $B$, Section 2.0. The masses of 211 of the radionuclides 1 isted in Table B5-1 are found by multiplying the activities by the specific activities as taken from Nuclear Criticality Safety in Operations with Fissionable Material Outside Reactors (ANSI/ANS 1983). The resulting total fissile isotope mass in the shipment is less than $15 \mathrm{~g}(0.21 \mathrm{oz})$. Therefore, the shipment is fissile excepted, and criticality safety is not an issue.

Table B5-1. Masses of Fissile Isotopes.

\begin{tabular}{|l|c|c|c|}
\hline \multicolumn{1}{|c|}{ Isotope } & $\begin{array}{c}\text { Specific activity } \\
(\mathrm{Ci} / \mathrm{g})\end{array}$ & $\begin{array}{c}\text { Total activity } \\
(\mathrm{C} i)\end{array}$ & $\begin{array}{c}\text { Total mass } \\
(\mathrm{g})\end{array}$ \\
\hline${ }^{233 \mathrm{U}}$ & $9.64 \mathrm{E}-03$ & $2.05 \mathrm{E}-05$ & $2.13 \mathrm{E}-03$ \\
\hline${ }^{235} \mathrm{U}$ & $1.92 \mathrm{E}-06$ & $1.26 \mathrm{E}-06$ & $6.56 \mathrm{E}-01$ \\
\hline${ }^{238} \mathrm{Pu}$ & $1.71 \mathrm{E}+01$ & $3.81 \mathrm{E}-03$ & $2.23 \mathrm{E}-04$ \\
\hline${ }^{239} \mathrm{Pu}$ & $6.20 \mathrm{E}-02$ & $8.79 \mathrm{E}-03$ & $1.42 \mathrm{E}-01$ \\
\hline${ }^{241} \mathrm{Pu}$ & $1.03 \mathrm{E}+02$ & $3.55 \mathrm{E}-01$ & $3.45 \mathrm{E}-03$ \\
\hline Total & & $8.04 \mathrm{E}-01$ \\
\hline
\end{tabular}

\subsection{REFERENCES}

49 CFR 173.401, 1994, "Shippers--General Requirements for Shipments and Packagings," .401, "Scope," Code of Federa7 Regulations, as amended.

ANSI/ANS, 1983, Nuclear Criticality Safety in Operations With Fissionable Material Outside Reactors, ANSI/ANS 8.1-1983, American National Standards Institute, New York, New York. 
WHC-SD-TP-SEP-050 Rev. 0

This page intentionally left blank. 
WHC-SD-TP-SEP-050 Rev. 0

\subsection{STRUCTURAL EVALUATION}

\subsection{INTRODUCTION} tank.

This evaluation determines the structural adequacy of the B Plant organic

\subsection{STRUCTURAL EVALUATION OF PACKage}

\subsubsection{Structural Design and Features}

Specifications for the tank are as described in Part A, Section 2.0.

\subsubsection{Mechanical Properties of Materials}

The tank heads and shell are certified to have a minimum 206.84-MPa $(30,000-p s i)$ yield strength and a $517.11-\mathrm{MPa}(75,000-p s i)$ ultimate tensile strength.

\subsubsection{Chemical and Galvanic Reactions}

The tank shell and heads are manufactured from 304 stainless steel. This material is compatible with the organic waste and is used for many of the B Plant components that handle this material, including the storage cells.

\subsubsection{Size of Package and Cavity}

See Part A, Section 2.0.

\subsubsection{Weights and Center of Gravity}

See Part A, Section 2.4

\subsubsection{Tamper-Indicating Feature}

Tamper-indicating features will not be required for transportation due to the short length of the trip and the controlled environment of the Hanford Site; however, tamper-indicating features may be added at the storage location.

\subsubsection{Positive Closure}

The tank has no openings below the surface of the liquid. Top openings are either flanged or valved and provide positive closure. 
WHC-SD-TP-SEP-050 Rev. 0

\subsubsection{Lifting and Tiedown Devices}

See Part A, Sections 2.9 and 2.10.

\subsubsection{Brittle Fracture} $\left(-20^{\circ} \mathrm{F}\right)$.

The tank is certified for a minimum design temperature of $-28.9{ }^{\circ} \mathrm{C}$

\subsection{NORMAL TRANSFER CONDITIONS}

\subsubsection{Conditions To Be Evaluated}

The tank, in its original configuration, was certified to meet DOT requirements for offsite shipping of LSA material. No additional structural evaluations will be performed because the payload weighs less than the certified payload (lower specific gravity); the payload meets LSA requirements (see Part B, Section 2.1.2); and the modifications do not affect the structural integrity of the tank (see Part B, Section 3.4).

It should be noted that to meet these DOT requirements, the tank must be at least $80 \%$ full during transport to prevent load shift and potential tipping. Since there is a possibility that the tank may be less than $80 \%$ full, speed restrictions are imposed. See Part A, Section 4.3.

\subsection{STRUCTURAL EVALUATION AND CONCLUSIONS}

It is concluded that the tank meets the requirements for normal and accident conditions because in its original configuration the tank was certified to meet DOT requirements for offsite shipping of LSA material, the B Plant payload weighs less (lower specific gravity) and meets LSA requirements, and the modifications do not affect the structural integrity of the tank. 
WHC-SD-TP-SEP-050 Rev. 0

\subsection{THERrAL EVALUATION}

\subsection{INTRODUCTION}

The purpose of this evaluation is to show that the B Plant organic tank is not threatened by heat generated by the payload during normal transfer conditions.

\subsection{THERMAL SOURCE SPECIFICATION}

The Radcalc program was used to determine the total heat generation from all isotopes in the payload (see Part B, Section 8.3). The majority of the heat is generated by ${ }^{90} \mathrm{Sr}(0.87 \mathrm{~W})$, and the total payload heat generation is less than $1 \mathrm{~W}$.

\subsection{SUMMARY OF THERIAL PROPERTIES OF MATERIALS}

The tank is certified for a maximum temperature of $121^{\circ} \mathrm{C}\left(250^{\circ} \mathrm{F}\right)$.

\subsection{THERMAL EVALUATION AND CONCLUSIONS}

The amount of thermal output from the waste is negligible (less than $1 \mathrm{~W}$ per package). Therefore, the payload will not cause the tank to exceed the requirements of 49 CFR 173.442, or the maximum certified temperature of the tank $121^{\circ} \mathrm{C}\left(250^{\circ} \mathrm{F}\right)$, and no further thermal evaluation is required.

\subsection{REFERENCES}

49 CFR 173.442, 1994, "Shippers--General Requirements for Shipments and Packagings," .442, "Thermal Limitations," Code of Federal Regulations, as amended. 
WHC-SD-TP-SEP-050 Rev. 0

This page intentionally left blank. 


\subsection{PRESSURE AND GAS EVALUATION}

\subsection{GAS GENERATION}

The purpose of this evaluation is to predict hydrogen gas generation rate and pressure buildup in the tank. Equilibrium hydrogen concentration with open filters will also be determined.

\subsection{PACKage pressure and flamable gas conclusions}

The analysis presented in Section 8.3.1 shows that the hydrogen generation rate is $43.5 \mathrm{~cm}^{3} / \mathrm{h}$. The pressure increase from the hydrogen is also considered. The analysis presented in Part B, Section 8.3.1, shows that the pressure would increase by $2.6 \mathrm{kPa}$, based on an increase in hydrogen concentration of $2.5 \%$. The actual pressure increase will be much less than this because the increase in hydrogen concentration is limited to $0.5 \%$. Because the tank is certified for a gauge pressure of $689 \mathrm{kPa}$ (100 psi), the pressure increase from hydrogen is not a concern. 


\subsection{APPENDIX: HYOROGEN GENERATION EVALUATIONS}

$+$

ENOTNEEXNO SAFETY EYALUATION

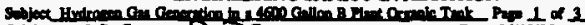

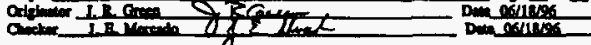

I.

Onindirats

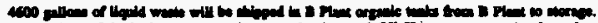

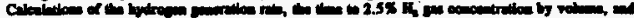

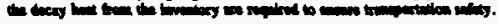

1. Proman

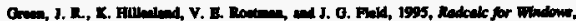

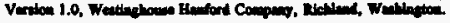

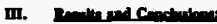

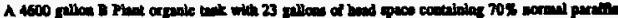

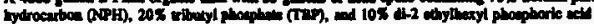

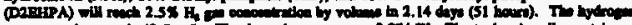

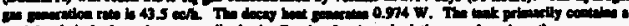

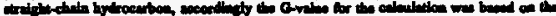

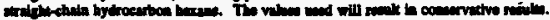

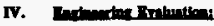

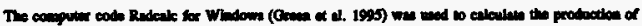

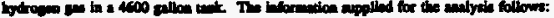

\begin{tabular}{|c|c|c|c|}
\hline Woese Vohm & 4600 enllan & . & \\
\hline Towl Trat Vohne & 4623 gallon: & 7 & \\
\hline Wete Dentity & 0.015 elec & & \\
\hline Wots Moris & $70 \%$ NER & $20 \times \mathrm{TP}$ & 10\%ogerire \\
\hline Rudiometive Components & \multicolumn{3}{|l|}{ Ses Table 1.} \\
\hline
\end{tabular}

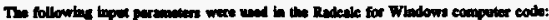

\begin{tabular}{|c|c|c|c|}
\hline Wat Vohus & $17.4120=$ & & \\
\hline Void Volume & $0.0571 \mathrm{~m}$ & & \\
\hline Wha Welute & $1.4 \times 10^{\circ}$ & & \\
\hline 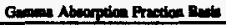 & LR-56 & & \\
\hline G-value & Emons 5 & bets 5 & llohe: 20 \\
\hline 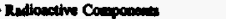 & sen The 1 & & \\
\hline
\end{tabular}




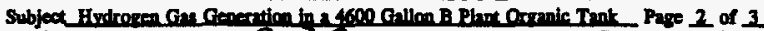

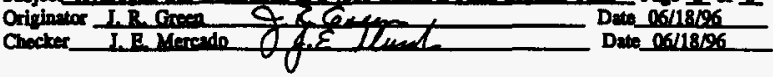

The fraction of gammen sbecrbed in the wate tank is a function of energy and peonetry. The moet conervative value for the gamme sbopption frection contained in Radcale for Windows are those which are celcalned for the LR-56. Therefore, the LR-S6 container was ued to model the tank bectuse the $B$ Plant organic tunk in not modeled within the code.

The $\mathrm{H}_{2} \mathrm{G}$-valos is a meare of the number of molecules of $\mathrm{H}_{2}$ gan formed per $100 \mathrm{oV}$ of enery sbecibed in the waste mitrix. G-values are applied in Redeale for Windowe for a variety of meveriat types. The liquid wate to be enipped is the tank trucks is primarily composed of a atratght-chein

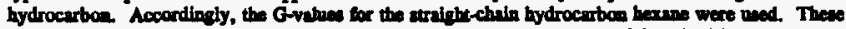
are $S$ for been and gamme, and 20 for atphe. To $G$-values are extremely bigh and will reanl in conservetive values for the material boing thipped.

The above paraneders were input into Rudcalc for Windows which calculated the number of daye to 2.5\% hydrogen gas concentration by volume to be 2.14 days (S1 hours). A copy of the Radeale input/output file is atteched. The uncertintion b this andlyis are represented primarily by the uncertainty of the G-value of the waste matrix. The valoe ued is very coneervative and may realt ha an over estimation of the quantity of hydrogen gae produced. 
$\downarrow$

ENGINEERING SAFETY EVALUATION

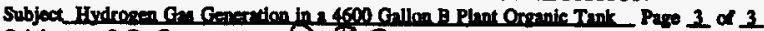
Origianter I.R. Frem. Checter I. E. Mercerdo

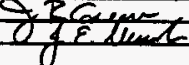
Date o6ases Date 0.6.18196

Table 1. B Plant Organic Wate Scurce Term.

\begin{tabular}{|c|c|c|c|}
\hline Inotope & $\begin{array}{c}\text { Total Activity } \\
\text { (C) }\end{array}$ & Inotape & $\begin{array}{c}\text { Total Activity } \\
\text { (C) }\end{array}$ \\
\hline $4 \mathbf{r}$ & $1.13 \mathrm{E}+0 \mathrm{I}$ & $1 \mathrm{Ba}$ & $1.46 \mathrm{E}-02$ \\
\hline$m s$ & $1.30 \mathrm{~B}+02$ & ${ }^{2} \mathrm{Eu}$ & $1.98 \mathrm{E}+\infty$ \\
\hline $\mathbf{Y}$ & $1.30 \mathrm{n}+\infty$ & ${ }^{16} \mathrm{Bu}$ & $7.82 \mathrm{E}-01$ \\
\hline 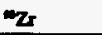 & $3.84 \mathrm{E}-03$ & $\sin \mathrm{Pz}$ & $2.65 \mathrm{E}-05$ \\
\hline re & $2.83 \mathrm{E}-02$ & $\mathrm{mh}$ & $2.65 \mathrm{~B}-0 \mathrm{~S}$ \\
\hline$m_{\mathbf{R u}}$ & $1.18 \mathrm{E}+\infty$ & ${ }^{m} U$ & $3.38 \mathrm{~B} 0 \mathrm{~s}$ \\
\hline mh & $1.18 \mathrm{~B}+\infty$ & $=\mathbf{u}$ & $8.71 \mathrm{~B}-06$ \\
\hline ised & $5.29 \mathrm{~B}-0 \mathrm{C}$ & ${ }^{\infty} U$ & $2.65 \mathrm{~B}-0 \mathrm{~S}$ \\
\hline${ }^{15 b}$ & $2.80 \mathrm{~B}+\infty$ & IPu & $3.81 \mathrm{~B}-03$ \\
\hline 125ere & $6.83 \mathrm{E}-01$ & Epr & $8.79 \mathrm{~B}-03$ \\
\hline${ }^{\mathrm{m} C}$ & $2.10 \mathrm{E}-01$ & ${ }^{20} \mathrm{Pu}$ & 4.65 E-03 \\
\hline${ }^{10} \mathrm{Cs}$ & $4.98 \mathrm{E}+00$ & ${ }^{31} \mathbf{P u}$ & $3.55 \mathrm{~B}-01$ \\
\hline $\mathrm{man}_{\mathrm{B}}$ & $4.71 \mathrm{E}+\infty 0$ & MAm & $7.42 \mathrm{E}-03$ \\
\hline${ }^{m} \mathrm{Ce}$ & $6.26 \mathrm{~B}-01$ & Am & 8.64 B-06 \\
\hline${ }^{{ }^{\prime}} \mathrm{Pr}$ & $6.26 \mathrm{~B}-01$ & ${ }^{-1 m}$ & $8.59 \mathrm{~B}-06$ \\
\hline $\operatorname{mop}_{\mathbf{r}}$ & $7.52 \mathrm{~B}-03$ & Total & $3.37 \mathrm{E}+02$ \\
\hline${ }^{10} \mathrm{Pm}$ & $4.39 \mathrm{E}+01$ & Total Beta & $3.32 \mathrm{~B}+02$ \\
\hline $115 \mathrm{Sm}$ & $2.01 \mathrm{E}+\infty 0$ & Total Alpha & $2.47 \mathrm{E}-02$ \\
\hline
\end{tabular}




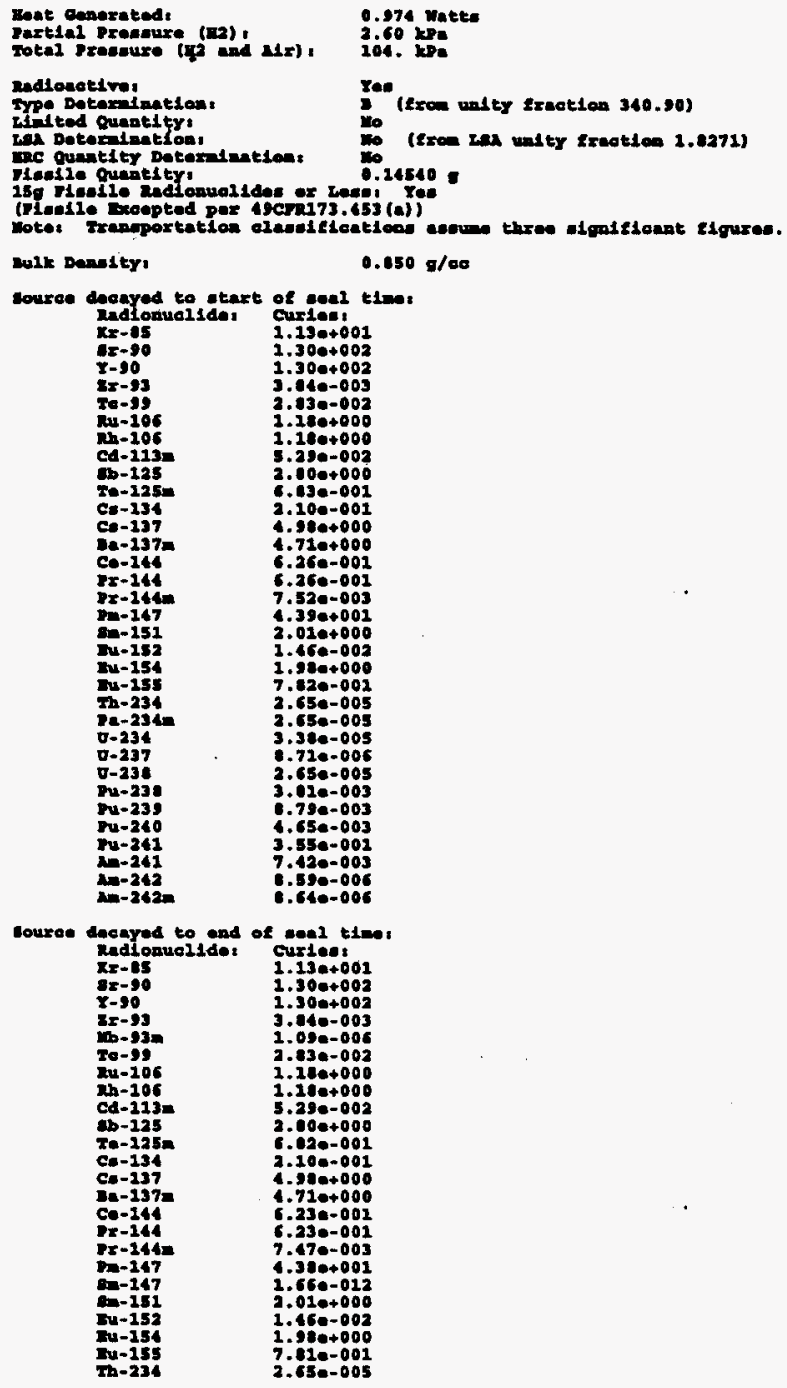


r11e: nowe.no

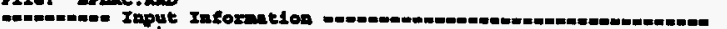

terree exoe Input:

nidionueltes Criter:

125-68 1.23e+001

$1 x-90 \quad 1.300+002$

$\begin{array}{rl}\mathrm{X}-100 & 1.300+002\end{array}$

Ex-93 3.84e-603

Te-95 2.030-002

Ru-105 $1.280+000$

in-106 $1.180+000$

cd-113n 5.25e-002

ab-125 $\quad 2.000+000$

2e-225 $\quad 6.930-001$

co-234 2.10e-001

Ce-137 4.9804000

E-1370 $\quad 4.714+000$

ce-144 6.26e-001

Pr-145 $\quad$ G.26e-001

7x-1440 7.510-00J

r-147 4.35e+607

C-151 2.01e+000

Eu-152 1.46e-002

Eu-154 1.92e+000

Gu-15B 7.62e-601

Th-236 2.550-005

Pe-231 $\quad 2.65 e-005$

0-234 3.35e-0os

0-237 0.71-006

0-230 2.65e-005

pu-23: 3.01e-043

$\begin{array}{ll}\text { Pu-239 } & .790-002\end{array}$

Pu-240 4.650-003

Pu-241 3.55e-002

$\mathrm{xin}-241 \quad 7.420-003$

$\mathrm{n}-242$ a.se-005

Neste Jome: rormal

0.64 -005

physidal Doxer ilquid

Costatuer apet in-56

Packege Votd Volumes

Weete Volume:

Ware rases

Wante Frue Deasity

\section{$0.710+004 \mathrm{co}$ \\ $1.740+007$ ee \\ $1.46+007 \mathrm{~g}$}

0.050 g/ea

bete to begla souroe deagy $13: 00 \mathrm{Kny}, 24,1996$

pate oontainer pealod: $13: 00$ may. 24, 1996

Deye to deesy courae before ceed tiver 0.00 dara

celculete nuber of diye cealed until 2.504 bydrogen is reeohed.

ratered o values:

20 ilphe 5 ate

coment

4,600 cellong of wete coneleting ofs

704 romil perafin wydroourbon

204 Tributyl Bhovphes

204 D1-2 othyinexy photphorle add

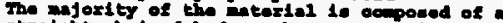

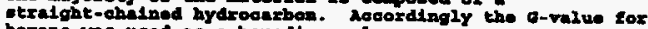

berane wa wed ex a boundise velue.

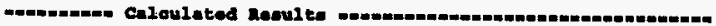

The sealed conteiner w11 generete 2.50 bydrogen in 2.14 daye

Thle oorferponde te date 16.00 uny. 26, igs

an volum

ne coneretion netes

$2.230+003$ ae

43.5 ec/hour 
WHC-SD-TP-SEP-050 Rev. 0

\begin{tabular}{|c|c|c|}
\hline 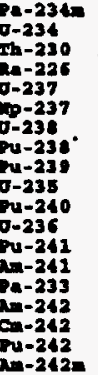 & 6 & $\begin{array}{l}2.650-005 \\
3.30-005 \\
1.700-012 \\
2.260-015 \\
.710-005 \\
1.410-011 \\
2.65-005 \\
3.010-003 \\
.790-003 \\
3.07=-014 \\
1.65=-003 \\
.060-013 \\
3.550-001 \\
7.420-003 \\
3.790-013 \\
0.50-005\end{array}$ \\
\hline
\end{tabular}


WHC-SD-TP-SEP-050 Rev. 0

This page intentionally left blank. 


$$
\text { WHC-SD-TP-SEP-050 Rev. } 0
$$

\subsection{PACKage tiedown SySten EVALUATION}

\subsection{SYSTEN DESIGN}

The tank frame shall be attached to the trailer via the four bottomcorner fittings. The trailer shall be equipped with four twist-lock fittings. Each twist-lock shall mate with its corresponding bottom-corner fitting and shall provide a strength that is equivalent to or greater than the strength of the corner fitting.

\subsection{ATtACHMENTS AND RATINGS}

The tiedown system has been certified for a maximum gross weight of $30,480 \mathrm{~kg}(67,200 \mathrm{lb})$, consisting of the 4,604-kg $(10,150-1 \mathrm{~b})$ tank assembly and the $25,876-\mathrm{kg}(57,050-1 \mathrm{~b})$ original payload.

The payload for this shipment will weigh less than $17,500 \mathrm{~kg}(38,581 \mathrm{lb})$. This weight is based on the conservative assumptions that the payload will consist of a volume of $17,500 \mathrm{~L}(4,623 \mathrm{gal})$ with a specific gravity of 1 . Because this is $8,376 \mathrm{~kg}(18,469 \mathrm{lb})$ less than the certified payload weight, no further analysis is required. 


\begin{tabular}{|c|c|c|c|c|c|}
\hline \multicolumn{6}{|c|}{ DISTRIBUTION SHEET } \\
\hline \multirow{2}{*}{$\begin{array}{l}\text { To } \\
\text { Distribution }\end{array}$} & \multirow{2}{*}{\multicolumn{3}{|c|}{$\begin{array}{l}\text { From } \\
\text { Packaging Engineering }\end{array}$}} & \multicolumn{2}{|l|}{ Page 1 of 1} \\
\hline & & & & \multicolumn{2}{|c|}{ Date Oct. 2, 1996} \\
\hline \multicolumn{4}{|l|}{ Project Title/Work Order } & \multicolumn{2}{|c|}{ EDT No. 618183} \\
\hline \multicolumn{4}{|c|}{$\begin{array}{l}\text { Safety Evaluation for Packaging for Onsite Transfer of B Plant } \\
\text { Organic Waste (WHC-SD-TP-SEP-050) }\end{array}$} & \multicolumn{2}{|l|}{ ECN No. $N / A$} \\
\hline Name & MSIN & $\begin{array}{l}\text { Text } \\
\text { With All } \\
\text { Attach. }\end{array}$ & Text Only & $\begin{array}{l}\text { Attach.l } \\
\text { Appendix } \\
\text { Only }\end{array}$ & $\begin{array}{l}\text { EDT/ECN } \\
\text { Only }\end{array}$ \\
\hline $\begin{array}{l}\text { H. E. Adkins, Jr. } \\
\text { R. L. Clawson } \\
\text { J. G. Field } \\
\text { J. R. Green } \\
\text { J. Greenborg } \\
\text { C. R. Hoover } \\
\text { D. W. McNally } \\
\text { M. M. Serkowski } \\
\text { S. S. Shiraga } \\
\text { Central Files } \\
\text { Deetment Processing-Contor } \\
\text { WHC-SD-TP-SEP-050 File } \\
\end{array}$ & $\begin{array}{l}\text { GI-11 } \\
\text { GI-13 } \\
\text { GI-11 } \\
\text { GI-11 } \\
\text { HO-35 } \\
\text { G1-11 } \\
\text { G1-11 } \\
\text { S4-66 } \\
\text { G1-11 } \\
\text { A3-88 } \\
\text { A3-94 } \\
\text { G1-11 } \\
\end{array}$ & $\begin{array}{l}x \\
x \\
x \\
x \\
x \\
x \\
x \\
x \\
x \\
x \\
x \\
x \\
x\end{array}$ & & & \\
\hline
\end{tabular}

